\title{
Organic petrology and geochemistry of Triassic and Jurassic coals of the Tabas Basin, Northeastern/Central Iran
}

\author{
Nazanin Zamansani ${ }^{1} \cdot$ Mohammad Ali Rajabzadeh $^{1} \cdot$ Ralf Littke $^{2} \cdot$ \\ Laura Zieger ${ }^{2} \cdot$ Alireza Baniasad $^{2}$
}

Received: 13 October 2018/Revised: 1 July 2019/Accepted: 4 July 2019/Published online: 18 July 2019

(C) The Author(s) 2019

\begin{abstract}
Jurassic and Triassic coals and organic matter-rich shales of the Tabas Basin, Iran, were investigated with respect to their thermal maturation and petrographic composition. The Triassic coals of the Parvadeh coal field range in vitrinite reflectance between $1.17 \%$ and $1.37 \%$ and the Jurassic coals of the Mazino coal field between 2.08\% and 2.29\% $\mathrm{VR}_{\mathrm{r}}$. Maceral analysis revealed a predominance of vitrinite in all samples, with slightly higher percentages of inertinite in the Jurassic samples. Rock-Eval analyses confirm the presence of type III kerogen in the Triassic coals, while the Jurassic coals contain strongly carbonized residual kerogen. The range of sulfur contents for coals from the Parvadeh coal field $(0.37 \%$ to $4.64 \%)$ and Mazino coal field $(0.45 \%$ to $2.92 \%)$ is related to the effect of marine water in peat. The studied samples are characterized by the predominance of short- over long-chained $n$-alkanes. The relatively high $\operatorname{Pr} / \mathrm{Ph}$ ratios indicate predominance of terrestrial organic matter whereas $\mathrm{Pr} / n-\mathrm{C}_{17}$ and $\mathrm{Ph} / n-\mathrm{C}_{18}$ ratios prove oxic conditions during deposition. In addition, the DBT/Phen ratio shows that these coals formed in fluvial/deltaic environments. Molecular geochemical parameters such as carbon preference index (CPI, 0.99-1.04), methyl phenanthrene index (MPI, 1.20-1.60), methyl naphthalene ratio (MNR, 1.61-3.45), and ethyl naphthalene ratio (ENR, 4-6.78) confirm the high maturity of the samples. Burial and thermal history reconstruction indicates necessity of an erosional thickness of about $4000 \mathrm{~m}$ in the Parvadeh area. Towards the Mazino area, a higher basal heat flow up to $80 \mathrm{~mW} \mathrm{~m}^{-2}$ is assumed for the Paleogene leading to higher maturities.
\end{abstract}

Keywords Jurassic coal $\cdot$ Triassic coal $\cdot$ Vitrinite reflectance $\cdot$ Maceral $\cdot$ Organic geochemistry $\cdot$ Coal petrography

\section{Introduction}

Coal deposits of Iran are mainly located in the northern (e.g. Alborz Basin) and central part of the country (Tabas and Kerman Basins; Fig. 1). The Tabas Basin, located in the southern Khorasan province in northeastern Iran holds more than $60 \%$ of the country's coal reserves, and is thus the most important coal mining area. The bituminous coals

Mohammad Ali Rajabzadeh

mrajabzadeh@shirazu.ac.ir

1 Department of Earth Sciences, College of Sciences, Shiraz University, Shiraz, Iran

2 Energy and Mineral Resources Group (EMR), RWTH Aachen University, Aachen, Germany of the Parvadeh and Nayband coalfields are of Upper Triassic age and used for coke production, while Jurassic semianthracites are mined from the Mazino, Abdooghi, and Kalshaneh coalfields. This study deals with the organic geochemical and organic petrological characteristics of bituminous coals from the Parvadeh field as well as semianthracites from the Mazino coalfield (Fig. 1). The Parvadeh coalfield has an area of about $1200 \mathrm{~km}^{2}$ and is divided into six sections based on fault structures (Parvadeh 1-4, and northern-, and southeastern Parvadeh). The Parvadeh coal deposit consists of six major coal seams (A, $\mathrm{B}, \mathrm{C}, \mathrm{D}, \mathrm{E}$, and F) from which, based on quality and quantity of the coal, only three are exploitable (B, C, and D). In our study, we discuss some petrological and geochemical parameters of the $\mathrm{B}_{1}, \mathrm{~B}_{2}, \mathrm{C}_{1}$, and $\mathrm{D}$ seams, sampled in the Parvadeh sections 1-4. According to well 


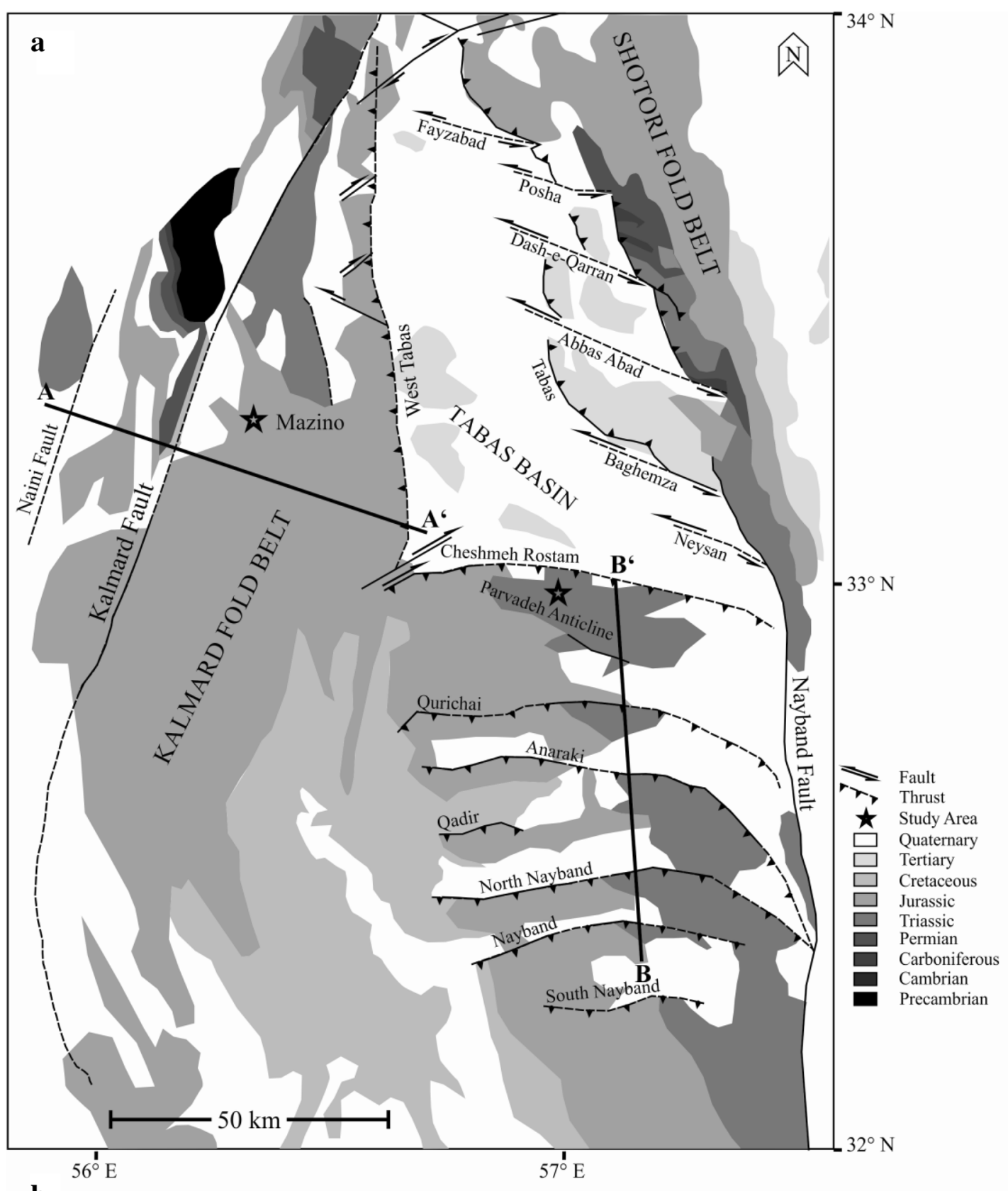

b

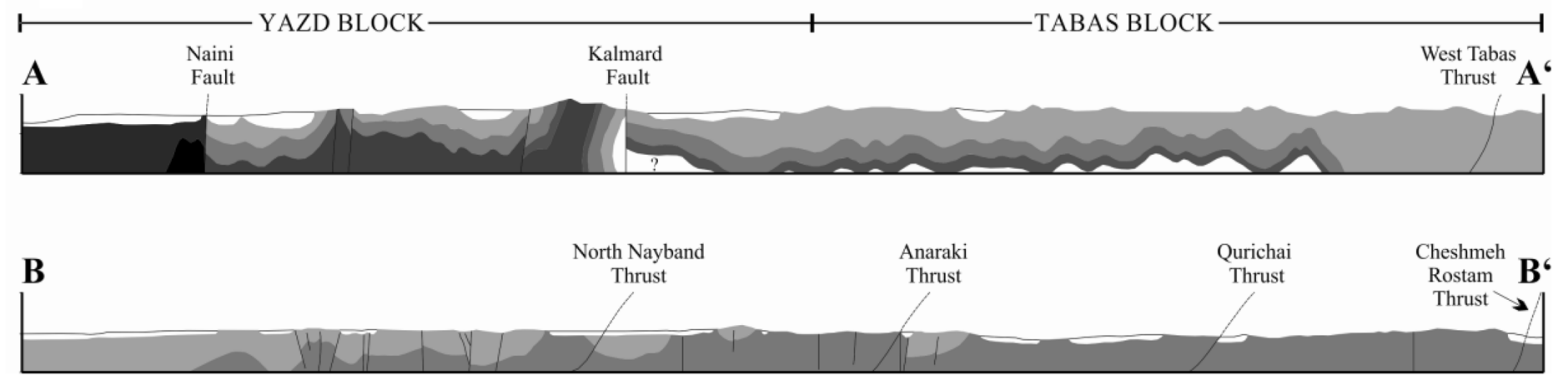

Fig. 1 a Geological map of Tabas block with sampling locations marked, b Geological cross sections along lines $\mathrm{AA}^{\prime}$ and $\mathrm{BB}^{\prime}$. Modified after Konon et al. (2016) 
logs, the Mazino coal deposit consists of more than 120 coal layers. In this study, we focus on the three layers exploitable within the Chahrekhneh mine $\left(\mathrm{K}_{1}, \mathrm{~K}_{2}\right.$, and $\left.\mathrm{K}_{3}\right)$. As compared to Permian and Carboniferous coals on the one hand and Cenozoic coals and lignites on the other hand, Mesozoic coals have been much less studied in the past. Furthermore, only little information is available on coals of the Middle East, of which those of Turkey are best studied. Although the mineralogy, inorganic geochemistry, and stratigraphy of the Mesozoic coals of Iran have been investigated by several authors (e.g. Pazand 2015; Goodarzi et al. 2006; Ghassabiyan et al. 2010; Moore and Esmaeili 2012; Ardebili et al. 2012; Moosavirad et al. 2013; Ghavidel-Syooki et al. 2015; Rajabzadeh et al. 2016), only little information is available on the characteristics of organic material that formed these coals (Solaymani and Taghipour 2012; Stasiuk et al. 2006; Alizadeh et al. 2011, 2015; Ghavidel-Syooki et al. 2015). In order to investigate depositional conditions, plant input and thermal maturity of the aforementioned Iranian coal deposits, a wide range of organic petrological and organic geochemical methods was applied. This paper will provide first detailed data on the organic matter in the Triassic and Jurassic coals of the Tabas Basin. In addition, a first numerical model on burial and uplift of the Tabas Basin is presented based on the maturity data and geological information.

\section{Geological setting}

The Tabas Basin is part of the Central Iranian Micro Continent (Takin 1972; Fürsich et al. 2009; Wilmsen et al. 2009) and located at the central part of the Tabas Block, which is separated by the Nayband Fault to the east and the Kalmard-Kouhbanan Fault to the west from the Yazd and the Lut Blocks, respectively (Alavi 1996; Ghassabiyan et al. 2010, see Fig. 1). The basin is characterized by E-Wtrending faults and fault-related folds in the east and N-Strending faults in the west (Fig. 1). The basin formed as a result of the closure of the Paleo-Tethys Ocean during the Late Permian to the Late Triassic (Fürsich et al. 2009), when the Iranian plate moved northwards, from an equatorial position to about $25^{\circ}$ northern latitude during the Jurassic (Fig. 2, Mattei et al. 2015; Wilmsen et al. 2009; Bordenave and Hegre 2005), always at the northern border of the Neo-Thetys Ocean (Stampfli and Borel 2002). The Tabas Basin holds five major coal deposits, namely the Parvadeh, Nayband, Mazino, Abdooghi, and Kalshaneh coalfields (Ahangaran et al. 2011). A large area of the Tabas Block subsided from the Upper Triassic until the Middle Cretaceous, accompanied by rifting activities. The most important coal-bearing layers in the Tabas Basin formed between the Middle Carnian (Late Triassic) and the Bajocian (Middle Jurassic) within the Shemshak Group (Yazdi and Shiravani 2004). The Shemshak Group is an important unit hosting Mesozoic coals in several basins such as the Alborz, Tabas, and Kerman Basins (Moosavirad et al. 2013; Goodarzi et al. 2006; Moore and Esmaeili 2012; Ghassabiyan et al. 2010). This group deposited in a continental lagoonal setting and consists, from old to young, of the Nayband, the Ab-e-Haji, the Badamu, and the Hojedk Formations (Fig. 3). Ghassabiyan et al. (2010) suggested that the Shemshak Group megasequence probably formed in a foreland basin in front of tectonically active blocks. The Shemshak Group within the Tabas Basin overlies the Shotory Formation and is unconformably overlain by the Parvadeh Formation of the Magu Group, which formed in a shallow marine environment (Stöcklin et al. 1965; Ghassabiyan et al. 2010; Fig. 2). The Cretaceous sequence in the Tabas Basin includes shallow marine deposits, e.g. red coarse-grained sandstone, pebbly sandstone to limestone, marlstone, and conglomerate. The Cenozoic sediments in the Tabas Block consist of marl, gypsiferrous marl, and thick-bedded Neogene/Quaternary sediments (Ghassabiyan et al. 2010). In the Parvadeh coalfield, coal layers occur within the Upper Triassic Nayband Formation that has a thickness of about $1800 \mathrm{~m}$ and is separated into four members which are, from bottom to top: the Bidestan Member, build up by $120 \mathrm{~m}$ of shale, siltstone, and sandstone with sandy limestone and marl; the Howze Sheikh Member, consisting of $240 \mathrm{~m}$ of shale, followed by siltstone and finally sandstone; the Howze Khan Member, with $230 \mathrm{~m}$ of shale and sandstone; and the Ghadir Member with a thickness of more than $1000 \mathrm{~m}$ consisting of sandstone, shale, limestone, and coal layers (Rajabzadeh et al. 2016; Ghavidel-Syooki et al. 2015). Coal-bearing layers of the Mazino coalfield are hosted by the Middle Jurassic Hojedk Formation, with a thickness of about $60 \mathrm{~m}$, consisting of sandstone, siltstone, shale, and coal seams (Ghassabiyan et al. 2010).

\section{Materials and methods}

\subsection{Samples}

Fifteen samples of coal and organic matter-rich clay stone were collected from different mines within the Parvadeh and Mazino deposits after removing the weathered surface. The sample set covers several coal seams, which are accessible in the Chahrekhneh mine and several mines in the Parvadeh coalfield (Table 1). All samples were used for organic petrology, elemental analysis, ash content measurement, and Rock-Eval pyrolysis. In addition, molecular 


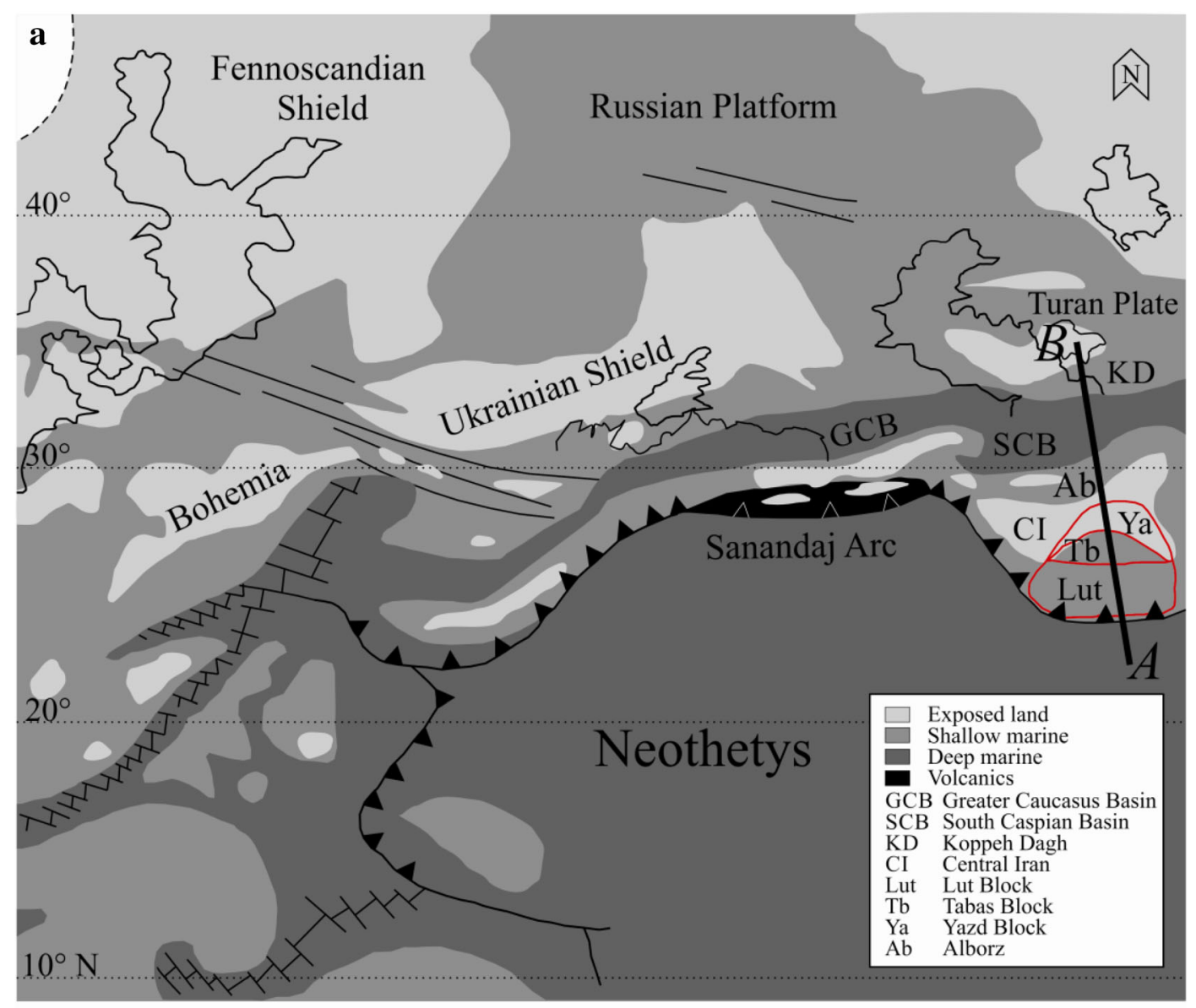

\section{b}

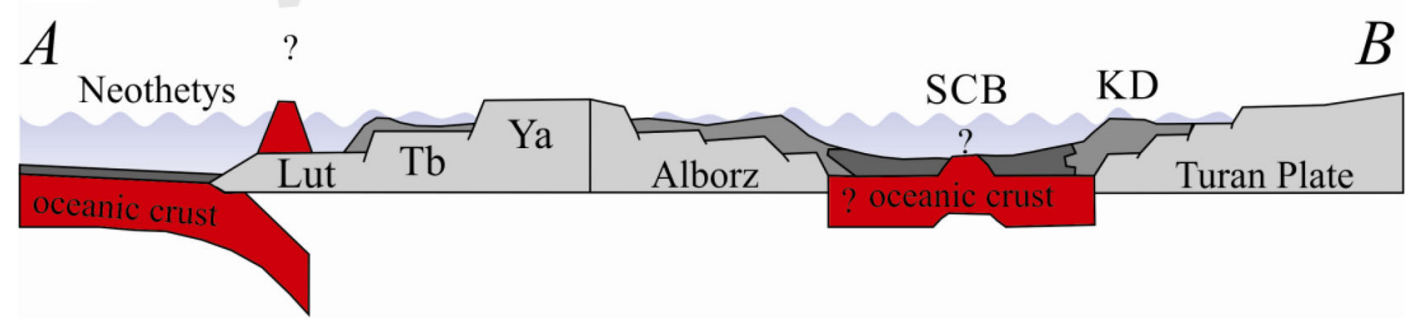

Fig. 2 a Palaeogeographic map of the western Neothetys during the middle Jurassic with the situation of the Central-East Iranian Microcontinent marked in red, b cross section along AB line. Modified after Wilmsen et al. (2009)

organic geochemistry was analyzed on 11 samples from the Parvadeh coalfield.

\subsection{Petrography}

For petrographic analysis, small pieces of rock and coal were embedded in a two-phase epoxy resin $\left(\right.$ Araldite $^{\circledR}$ ) and, after hardening, ground and polished following to the procedures described in detail in Littke et al. (2012). Analyses include maceral-group counting and vitrinite reflectance measurements. Maceral analyses were carried out by counting 500 points per sample on an equidistal grid, following the Stopes-Heerlen system (Taylor et al. 1998), with an incident light microscope (Axio Imager, Zeiss), equipped with an automated stage at $500 \times$ magnification. Vitrinite reflectance (VRr) was measured on 100 random points per sample with an Axioplan microscope (Zeiss), calibrated with a YAG (Yttrium-Aluminum-Garnet) standard $(0.89 \%)$. More information on microscopic device and measuring procedure can be found in Sachse et al. (2011). 


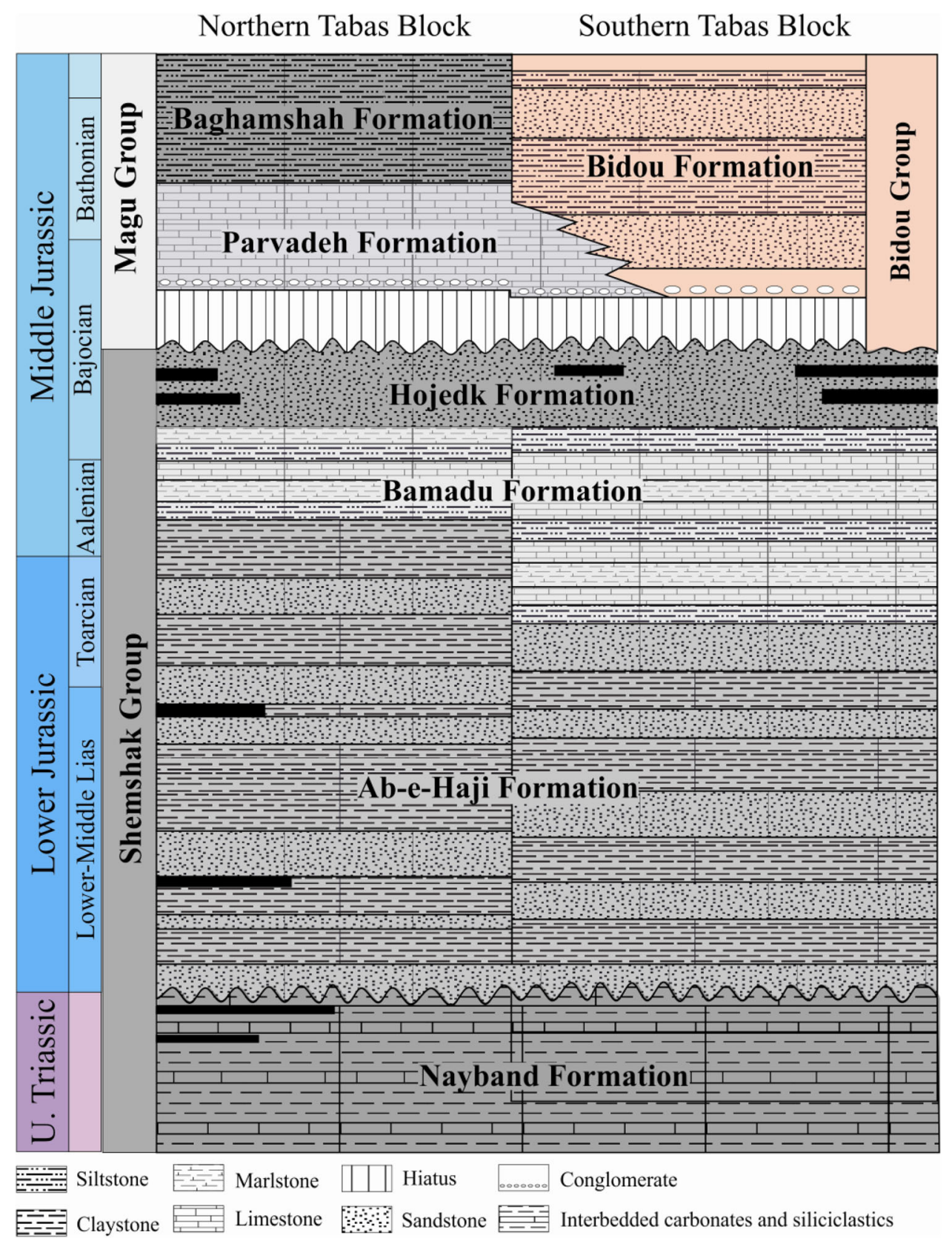

Fig. 3 Lithostratigraphy of the Upper Triassic to Middle Jurassic of the Tabas Block (northern and southern part). Modified after Wilmsen et al. (2009)

\subsection{Bulk and elemental analyses}

Prior to analyses, the samples were crushed to fine powders using a rotation mill. The measurement of total inorganic (TIC) and organic carbon (TOC) contents was performed using a LiquiTOC II analyzer (elementar) and the total sulfur content (TS) was measured with a total evaporation analyzer (Leco200).

Ash content was measured based on the DIN51719 standard which is in accordance to ISO 1171 . The waterfree sample $(1 \mathrm{~g})$ was first heated within $60 \mathrm{~min}$ to $500{ }^{\circ} \mathrm{C}$.
Temperature is then increased until $815^{\circ} \mathrm{C}$ is reached. This temperature is held for $60 \mathrm{~min}$. Each sample was further measured in triplets.

Rock-Eval pyrolysis was performed using a Rock-Eval VI apparatus (VINCI), using $20 \mathrm{mg}$ pulverized sample of the bituminous coals and $100 \mathrm{mg}$ of the semianthracites, respectively. Details of the analytical and device as well as the calculation of Rock-Eval parameters [S1, S2, S3, T $\max$, Hydrogen Index (HI), Oxygen Index (OI), and Production Index (PI)] are described in Behar et al. (2001). 
Table 1 Sample types and sampling locations

\begin{tabular}{lllll}
\hline Sample & Type & Age & Coalfield & Mine \\
\hline $17 / 2009$ & Organic rich claystone & Jurassic & Mazino & Chahrekhneh \\
$17 / 2010$ & Coal & Jurassic & Mazino & Chahrekhneh \\
$17 / 2011$ & Coal & Jurassic & Mazino & Chahrekhneh \\
$17 / 2012$ & Organic rich claystone & Jurassic & Mazino & Chahrekhneh \\
$17 / 2013$ & Organic rich claystone & Triassic & Parvadeh 3 & Madanjoo \\
$17 / 2014$ & Coal & Triassic & Parvadeh 3 & Madanjoo \\
$17 / 2015$ & Coal & Triassic & Parvadeh 3 & Madanjoo \\
$17 / 2016$ & Coal & Triassic & Parvadeh 3 & Madanjoo \\
$17 / 2017$ & Coal & Triassic & Parvadeh 2 & Negin \\
$17 / 2018$ & Organic rich claystone & Triassic & Parvadeh 2 & Negin \\
$17 / 2019$ & Organic rich claystone & Triassic & Parvadeh 2 & Negin \\
$17 / 2020$ & Coal & Triassic & Parvadeh 3 & Negin \\
$17 / 2021$ & Coal & Triassic & Parvadeh 3 & Negin \\
$17 / 2022$ & Coal & Triassic & Parvadeh 1 & Parvadeh \\
$17 / 2023$ & Coal & Triassic & Parvadeh 4 & Samanfaraz \\
\hline
\end{tabular}

\subsection{Molecular geochemistry}

An amount of 3-5 g (based on TOC contents) of homogenized sample was extracted with a fully automatic DIONEX ASE 150 instrument (Thermo Scientific). Extraction was performed using dichloromethane under high temperature and pressure conditions $\left(100{ }^{\circ} \mathrm{C}, 100\right.$ bars $)$. The solvent was then changed to $n$-hexane and the total amount was reduced to $0.5 \mathrm{ml}$ using rotary evaporation. The samples were subsequently dried with anhydrous sodium sulfate and finally desulfurized. The extracts were separated into two fractions (aliphatic and aromatic) by liquid chromatography on a micro column using $2 \mathrm{~g}$ of activated silica gel. For activation, the column was kept in the oven at $200{ }^{\circ} \mathrm{C}$ for $15 \mathrm{~h}$ prior to chromatography. The aliphatic fraction was eluted with five $\mathrm{ml}$ of $n$-pentane. $5 \mathrm{ml}$ of a mixture of $n$-pentane and dichloromethane (40:60; v:v) were used to separate the aromatic hydrocarbons.

Both fractions were then concentrated to less than $0.2 \mathrm{ml}$ and analyzed by GC-FID. The analyses were performed with a Fisons Instruments GC 8000 series equipped with a split/splitless injector, flame ionization detector (FID), and Zebron ZB-1 HT Inferno fused silica column $(30 \mathrm{~m} \times 0.25 \mathrm{~mm}$ i.d., film thickness $0.25 \mu \mathrm{m}$, Phenomenex $\left.{ }^{\circledR}\right)$. Gas chromatography conditions were set to $270{ }^{\circ} \mathrm{C}$ injector temperature, $1 \mu$ splitless injection $(60 \mathrm{~s})$ at $80{ }^{\circ} \mathrm{C}, 3 \mathrm{~min}$ isothermal hold, then programmed at $5{ }^{\circ} \mathrm{C} \mathrm{min}{ }^{-1}$ to $310^{\circ} \mathrm{C}$, and held there for $20 \mathrm{~min}$. Hydrogen was used as carrier gas. GC-MS was performed on the aromatic fraction using a quadrupol mass spectrometer Trace MS (Thermoquest) linked to a Mega Series HRGC 5160 gas chromatograph (Carlo Erba, IT), equipped with a
$30 \mathrm{~m} \times 0.25 \mathrm{~mm} \times 0.25 \mu \mathrm{m}$ film Zebron ZB-5 fused silica capillary column. The chromatographic conditions were set to $270{ }^{\circ} \mathrm{C}$ injector temperature, $1 \mu \mathrm{l}$ split injection at $80{ }^{\circ} \mathrm{C}, 3 \mathrm{~min}$ isothermal hold, then programmed at $3{ }^{\circ} \mathrm{C} \mathrm{min}{ }^{-1}$ to $320{ }^{\circ} \mathrm{C}, 20 \mathrm{~min}$ isothermal hold. The mass spectrometer was operated in single ion mode $(\mathrm{EI}+, 70 \mathrm{eV})$ with a source temperature of $200{ }^{\circ} \mathrm{C}$. Helium was used as carrier gas. The GC-FID and GC-MS results were evaluated using Atlas and $\mathrm{X}$-calibur softwares, respectively.

\subsection{Basin modeling}

To better understand the burial and thermal history and examine different scenarios of erosion magnitude and basal heat flow values in the Tabas Basin, 1D modeling was performed in two different settings, i.e. the Parvadeh and Mazino coal fields. The present-day geometry of the coal fields including the horizon depths and lithologies as well as geological events in terms of deposition and erosion/ hiatus were used as the main input data. The models were reconstructed using the PetroMod software (Schlumberger; Version 2016). Vitrinite reflectance data were used as calibration tool (Senglaub et al. 2006; Hantschel and Kauerauf 2009; Hartkopf-Fröder et al. 2015). The basic concept of 1D basin modeling for outcrop areas has been described in detail in Nöth et al. (2001). To quantify burial and thermal evolution in the Parvadeh and Mazino areas, two pseudo wells have been reconstructed. The SilurianDevonian succession acts as the lower boundary and the models consist of 12 events, including one erosion event, which took place after Alpine orogeny from $34 \mathrm{Ma}$ to present-day. Due to the lack of sufficient information from 
Table 2 Input data used for modeling the burial and temperature history in the Parvadeh Area (see Table 3 for physical rock properties)

\begin{tabular}{|c|c|c|c|c|c|c|c|}
\hline $\begin{array}{l}\text { Event } \\
\text { no. }\end{array}$ & Event name & $\begin{array}{l}\text { Age at Top } \\
\text { (Ma) }\end{array}$ & $\begin{array}{l}\text { Thickness } \\
(\mathrm{m})\end{array}$ & Lithology & $\begin{array}{l}\text { PWD } \\
(\mathrm{m})\end{array}$ & $\begin{array}{l}\text { SWIT } \\
\left({ }^{\circ} \mathrm{C}\right)\end{array}$ & $\begin{array}{l}\mathrm{HF} \\
\left(\mathrm{mW} \mathrm{m}^{-2}\right)\end{array}$ \\
\hline 12 & $\begin{array}{l}\text { Eocene-Present-Day (Alpine orogeny and } \\
\text { Erosion) }\end{array}$ & 0 & 0 & & 0 & 20 & 48 \\
\hline 11 & Paleocene-Eocene & 34 & 0 & Andesite (igneous) & 10 & 22.86 & 48 \\
\hline 10 & U. Cretaceous-Paleocene & 65 & 0 & Conglomerate & 20 & 24.19 & 48 \\
\hline 9 & L. Cretaceous-U. Cretaceous & 100 & 0 & LiSt-Shale $(50: 50)$ & 30 & 28.38 & 48.5 \\
\hline 8 & U. Jurassic-L. Cretaceous & 145 & 0 & LiSt-Sand (50:50) & 40 & 27.17 & 49 \\
\hline 7 & M. Jurassic-U. Jurassic & 161 & 100 & LiSt-Shale $(50: 50)$ & 50 & 24.78 & 49.5 \\
\hline 6 & L. Jurassic-M. Jurassic & 171 & 100 & $\begin{array}{l}\text { Shale-Sand-LiSt } \\
\quad(40: 40: 20)\end{array}$ & 30 & 23.86 & 50 \\
\hline 5 & U. Triassic-L. Jurassic & 199 & 100 & $\begin{array}{l}\text { Shale-Sand-LiSt } \\
\quad(40: 40: 20)\end{array}$ & 40 & 22.36 & 50 \\
\hline 4 & L. Triassic-U. Triassic & 228 & 1800 & $\begin{array}{l}\text { Shale-Sand-LiSt } \\
(50: 25: 25)\end{array}$ & 40 & 26.15 & 51 \\
\hline 3 & Pennsylvanian-L. Triassic & 251 & 400 & $\begin{array}{l}\text { Shale-Dolomite } \\
\quad(70: 30)\end{array}$ & 40 & 25.42 & 50.7 \\
\hline 2 & M. Devonian-Pennsylvanian & 300 & 2000 & LiSt & 40 & 24 & 48 \\
\hline 1 & Llandovery-M. Devonian & 385 & 1350 & LiSt-Shale (50-50) & 30 & 24 & 48 \\
\hline
\end{tabular}

SWIT (sediment-water interface temperature) and HF (heat flow) are computed by PetroMod software. LiSt limestone, $P W D$ palaeowater-depth

Table 3 Physical parameters of the sedimentary rocks used in modeling in the Parvadeh Area (PetroMod default parameters for these lithologies)

\begin{tabular}{|c|c|c|c|c|c|c|c|c|c|c|c|}
\hline \multirow[t]{3}{*}{ Lithology } & \multicolumn{2}{|c|}{$\begin{array}{l}\text { Thermal } \\
\text { conductivity } \\
\left(\mathrm{W} / \mathrm{m}^{-1} \mathrm{~K}^{-1}\right)\end{array}$} & \multicolumn{3}{|c|}{ Radiogenic elements } & \multicolumn{3}{|c|}{ Heat capacity $\left(\mathrm{kcal} / \mathrm{kg}^{-1} \mathrm{~K}^{-1}\right)$} & \multicolumn{3}{|c|}{ Mechanical properties } \\
\hline & \multirow[t]{2}{*}{$20^{\circ} \mathrm{C}$} & \multirow[t]{2}{*}{$100{ }^{\circ} \mathrm{C}$} & \multirow[t]{2}{*}{$\begin{array}{l}\mathrm{U} \\
(\mathrm{ppm})\end{array}$} & \multirow[t]{2}{*}{$\begin{array}{l}\text { Th } \\
(\mathrm{ppm})\end{array}$} & \multirow[t]{2}{*}{$\begin{array}{l}\mathrm{K} \\
(\%)\end{array}$} & \multirow[t]{2}{*}{$20^{\circ} \mathrm{C}$} & \multirow[t]{2}{*}{$100{ }^{\circ} \mathrm{C}$} & \multirow[t]{2}{*}{$\begin{array}{l}\text { Density } \\
\left(\mathrm{kg} \mathrm{m}^{-3}\right)\end{array}$} & \multirow[t]{2}{*}{$\begin{array}{l}\text { Initial porosity } \\
(\%)\end{array}$} & \multicolumn{2}{|c|}{$\begin{array}{l}\text { Compressibility } \\
\left(\mathrm{GPa}^{-1}\right)\end{array}$} \\
\hline & & & & & & & & & & Max. & Min. \\
\hline Andesite (igneous) & 2.70 & 2.47 & 1.35 & 2.50 & 1.40 & 0.20 & 0.23 & 2650.0 & 5.00 & 0 & 0 \\
\hline Conglomerate & 2.30 & 2.18 & 1.50 & 4.00 & 2.00 & 0.20 & 0.23 & 2700.0 & 30.00 & 14.21 & 0.88 \\
\hline List-Shale (50-50) & 1.70 & 1.75 & 3.50 & 8.00 & 1.90 & 0.21 & 0.24 & 2665.0 & 59.00 & 248.88 & 3.08 \\
\hline List-Sand (50-50) & 3.44 & 3.02 & 1.15 & 2.25 & 0.75 & 0.20 & 0.23 & 2730.0 & 46.00 & 56.23 & 1.57 \\
\hline $\begin{array}{l}\text { Shale-Sand-List } \\
(40-40-20)\end{array}$ & 2.49 & 2.35 & 2.40 & 7.00 & 1.80 & 0.20 & 0.24 & 2714.0 & 54.00 & 186.03 & 2.45 \\
\hline $\begin{array}{l}\text { Shale-Sand-List } \\
\quad(50-25-25)\end{array}$ & 2.22 & 2.14 & 2.67 & 7.88 & 1.93 & 0.20 & 0.24 & 2712.5 & 57.25 & 225.67 & 2.77 \\
\hline $\begin{array}{l}\text { Shale-Dolomite } \\
\quad(70-30)\end{array}$ & 2.17 & 2.12 & 2.83 & 8.58 & 2.01 & 0.21 & 0.24 & 2727.0 & 59.50 & 289.86 & 3.15 \\
\hline List & 3.00 & 2.69 & 1.00 & 1.00 & 0.20 & 0.20 & 0.23 & 2740.0 & 51.00 & 85.00 & 1.98 \\
\hline
\end{tabular}

deep wells some input data including formation thickness, lithologies and ages had to be estimated based on the general geological information on Central Iran (Aghanabati 1998; Darvishzadeh 1991; Shahrabi 1999). Also to avoid confusion caused by formation names and to keep the models simple, the geological events were named based on the age instead of local names (Table 2). SWIT has been calculated applying the latitude of $33^{\circ}$ (Central Asia) (Wygrala 1989). A present-day heat flow of around $48 \mathrm{~mW} \mathrm{~m}^{-2}$ is assumed based on the crustal thickness variation in Central Iran (Tunini et al. 2015; see also Molinaro et al. 2005; Motavalli-Anbaran et al. 2011). Paleo basal heat flow ranged between 48 and $52 \mathrm{~mW} \mathrm{~m}^{-2}$ applying the Mackenzie Crustal Model (Jarvis and 
McKenzie 1980). A single rift phase occurred in the late Paleozoic (Bordenave and Hegre 2005). The input data for the Parvadeh area is provided in Table 2 and petrophysical rock properties in Table 3. Calibration of the model results was performed by comparing the measured and calculated reflectance applying the EASY $\% \mathrm{R}_{\mathrm{o}}$ algorithm of Sweeney and Burnham (1990).

\section{Results}

\subsection{Petrography}

The microscopic analyses showed that the major maceral group in the samples from both, the Parvadeh and Mazino deposits is vitrinite (V) although the samples from the Mazino deposit show a slight enrichment in inertinite (I). Liptinite was not detected in the samples. Microscopically counted mineral contents are not reported, because only small coal pieces were studied, which do not represent the entire samples. $\mathrm{VR}_{\mathrm{r}}$ of Triassic samples in the Parvadeh deposit ranges from $1.17 \%$ to $1.37 \%$, corresponding to medium volatile bituminous coal. Reflectance values of the Jurassic coals from the Mazino coalfield are higher and vary between $2.08 \%$ and $2.29 \%$, corresponding to semianthracite. Table 4 shows the relative contents of maceral groups in the analyzed Triassic and Jurassic samples. Pyrite and clay minerals are commonly present. The vitrinite of the Parvadeh samples shows small pores in low abundance, while vitrinite of the samples from the Mazino area shows large pores in high concentrations (Fig. 4).

\subsection{Bulk and elemental analyses}

TOC contents vary between $7.55 \%$ and $82.42 \%$ for the Triassic samples and between $25.85 \%$ and $82.00 \%$ for the

Table 4 Results of Rock-Eval pyrolysis, bulk analyses, and ash content as well as organic petrographical analyses

\begin{tabular}{|c|c|c|c|c|c|c|c|c|c|c|c|c|}
\hline \multirow[t]{2}{*}{ Sample } & \multirow[t]{2}{*}{ Age } & \multirow[t]{2}{*}{ Coalfield } & \multicolumn{4}{|c|}{ Bulk and elemental analyses } & \multicolumn{3}{|c|}{ Petrography } & \multicolumn{3}{|c|}{ Rock-Eval } \\
\hline & & & $\begin{array}{l}\text { TOC } \\
(w t \%)\end{array}$ & $\begin{array}{l}\text { TIC } \\
(w t \%)\end{array}$ & $\begin{array}{l}\mathrm{TS} \\
(\mathrm{wt} \%)\end{array}$ & $\begin{array}{l}\text { Ash } \\
\text { (wt } \%)\end{array}$ & $\begin{array}{l}\mathrm{VR}_{\mathrm{r}} \\
(\%)\end{array}$ & $\begin{array}{l}\mathrm{V} \\
(\operatorname{vol} \%)\end{array}$ & $\begin{array}{l}\text { I } \\
(\operatorname{vol} \%)\end{array}$ & $\begin{array}{l}T_{\max } \\
\left({ }^{\circ} \mathrm{C}\right)\end{array}$ & $\begin{array}{l}\mathrm{HI}(\mathrm{mg} \mathrm{HC} / \\
\text { TOC) }\end{array}$ & $\begin{array}{l}\text { OI }\left(\mathrm{mg} \mathrm{CO}^{2} / \mathrm{g}\right. \\
\text { TOC) }\end{array}$ \\
\hline $\begin{array}{l}17 / \\
2009\end{array}$ & Jurassic & Mazino & 25.85 & 0.05 & 0.45 & 62.48 & 2.16 & 80 & 20 & 611 & 7 & 4 \\
\hline $\begin{array}{l}17 / \\
2010\end{array}$ & Jurassic & Mazino & 60.10 & 0.15 & 2.92 & 29.24 & 2.29 & 60 & 40 & 592 & 11 & 1 \\
\hline $\begin{array}{l}17 / \\
2011\end{array}$ & Jurassic & Mazino & 82.00 & 0.01 & 1.30 & 5.09 & 2.14 & 41 & 59 & 611 & 7 & 1 \\
\hline $\begin{array}{l}17 / \\
2012\end{array}$ & Jurassic & Mazino & 33.88 & 0.03 & 2.15 & 52.18 & 2.08 & 99 & 1 & 611 & 6 & 3 \\
\hline $\begin{array}{l}17 / \\
2013\end{array}$ & Triassic & $\begin{array}{l}\text { Parvadeh } \\
\quad 3\end{array}$ & 7.55 & 0.15 & 3.88 & 84.08 & 1.25 & 61 & 39 & 465 & 82 & 5 \\
\hline $\begin{array}{l}17 / \\
2014\end{array}$ & Triassic & $\begin{array}{l}\text { Parvadeh } \\
\quad 3\end{array}$ & 55.98 & 0.15 & 2.32 & 34.56 & 1.24 & 88 & 12 & 471 & 139 & 1 \\
\hline $\begin{array}{l}17 / \\
2015\end{array}$ & Triassic & $\begin{array}{l}\text { Parvadeh } \\
3\end{array}$ & 68.03 & 0.10 & 1.73 & 22.58 & 1.19 & 90 & 10 & 462 & 144 & 1 \\
\hline $\begin{array}{l}17 / \\
2016\end{array}$ & Triassic & $\begin{array}{l}\text { Parvadeh } \\
\quad 3\end{array}$ & 67.32 & 0.12 & 2.16 & 22.84 & 1.37 & 96 & 4 & 465 & 125 & 1 \\
\hline $\begin{array}{l}17 / \\
2017\end{array}$ & Triassic & $\begin{array}{l}\text { Parvadeh } \\
\quad 2\end{array}$ & 52.84 & 0.94 & 1.33 & 36.68 & 1.25 & 78 & 22 & 470 & 104 & 0 \\
\hline $\begin{array}{l}17 / \\
2018\end{array}$ & Triassic & $\begin{array}{l}\text { Parvadeh } \\
\quad 2\end{array}$ & 18.05 & 0.22 & 0.37 & 73.35 & 1.32 & 99 & 1 & 473 & 122 & 10 \\
\hline $\begin{array}{l}17 / \\
2019\end{array}$ & Triassic & $\begin{array}{l}\text { Parvadeh } \\
\quad 2\end{array}$ & 19.90 & 0.11 & 0.41 & 71.66 & 1.22 & 96 & 4 & 470 & 128 & 2 \\
\hline $\begin{array}{l}17 / \\
2020\end{array}$ & Triassic & $\begin{array}{l}\text { Parvadeh } \\
\quad 3\end{array}$ & 81.49 & 0.01 & 2.71 & 9.82 & 1.25 & 100 & 0 & 478 & 183 & 2 \\
\hline $\begin{array}{l}17 / \\
2021\end{array}$ & Triassic & $\begin{array}{l}\text { Parvadeh } \\
3\end{array}$ & 52.93 & 0.10 & 0.94 & 37.45 & 1.23 & 82 & 18 & 477 & 173 & 3 \\
\hline $\begin{array}{l}17 / \\
2022\end{array}$ & Triassic & $\begin{array}{l}\text { Parvadeh } \\
\quad 1\end{array}$ & 82.42 & 0.00 & 4.64 & 7.00 & 1.33 & 96 & 4 & 480 & 224 & 3 \\
\hline $\begin{array}{l}17 / \\
2023\end{array}$ & Triassic & $\begin{array}{l}\text { Parvadeh } \\
\quad 4\end{array}$ & 71.30 & 0.01 & 2.67 & 13.75 & 1.17 & 91 & 9 & 461 & 86 & 6 \\
\hline
\end{tabular}



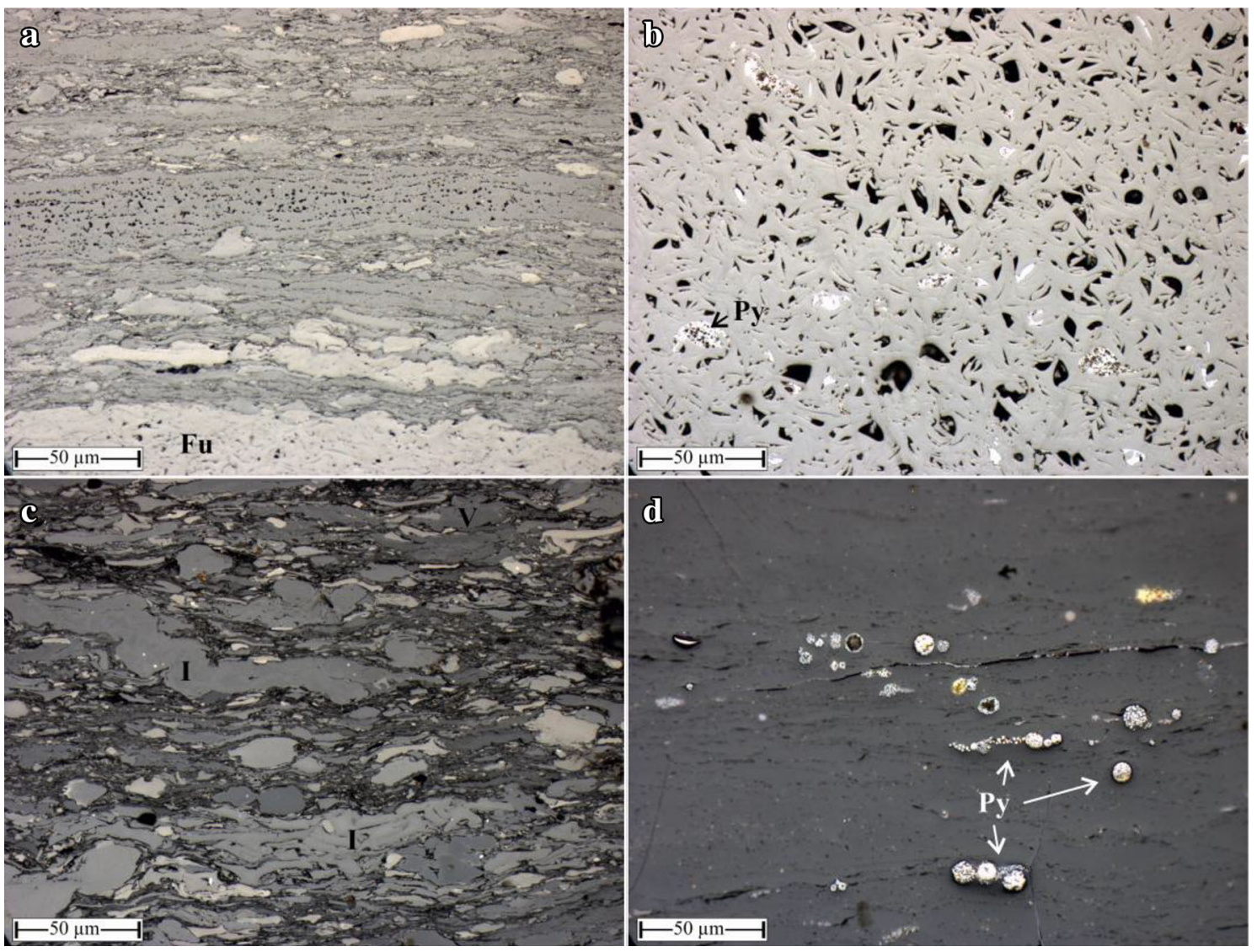

Fig. 4 Photomicrographs of coal samples of Parvadeh and Mazino coalfields (under oil immersion with reflected light): a typical vitriniteinertinite association with fusinite (FU) of a coal sample from the Mazino area. Note the abundant pores within the telovitrinite (center), b fusinite in a Mazino coal sample with pyrite (Py) precipitated in intercellular spaces, c exemplary microphotograph of a sample from the Parvadeh deposit showing inertinite particles (I) and gelovitrinites (V) in a matrix of detrovitrinite and clay minerals, $\mathbf{d}$ framboidal pyrites in vitrinite in a Parvadeh coal sample

Jurassic samples (Table 4), whereas TIC and, thus, carbonate contents are very low. The ash content of the Triassic samples varies between $7.00 \%$ and $84.00 \%$, while that of the Jurassic samples ranges between $5.09 \%$ and $62.00 \%$. TS contents of the Parvadeh and Mazino samples range from $0.37 \%$ to $4.64 \%$ and from $0.45 \%$ to $2.92 \%$, respectively (Table 4$)$. The sum of ash and TOC ranges from about $85 \%$ to $92 \%$ for the samples. This range can be expected due to the presence of about $8 \%$ to $15 \%$ (in total) organic nitrogen, sulfur, oxygen and hydrogen (Ragot 1977; Durand and Monin 1980; see Taylor et al. 1998).

HI varies between 82 and $224 \mathrm{mg} \mathrm{HC/g}$ TOC for the Triassic and between 6 and $11 \mathrm{mg} \mathrm{HC/g}$ TOC for the Jurassic samples. OI varies between 0 and $10 \mathrm{mg} \mathrm{CO} / \mathrm{g}$ TOC for the Triassic and between 1 and $4 \mathrm{CO}_{2} / \mathrm{g}$ TOC for the Jurassic samples (Table 4). Low OI values of coals have been commonly observed (Jasper et al. 2009) and do not reflect low $\mathrm{O} / \mathrm{C}$ ratios; they are related to the release of carbon monoxide rather than carbon dioxide and of oxygen-bearing organic molecules during Rock-Eval pyrolysis (Zieger et al. 2018). $\mathrm{T}_{\max }$ values range between 461 and
$480{ }^{\circ} \mathrm{C}$ for the Triassic and between 592 to $611{ }^{\circ} \mathrm{C}$ for the Jurassic samples (Table 4).

\subsection{Molecular geochemistry}

A typical GC-FID trace for the Triassic Parvadeh coals is shown in Fig. 5. For the Parvadeh samples the pristane/phytane ratio $(\mathrm{Pr} / \mathrm{Ph})$ varies between 2.51 and 5.46, whereas the $\mathrm{Pr} / n-\mathrm{C}_{17}$ and $\mathrm{Ph} / n-\mathrm{C}_{18}$ ratios vary between 0.11-0.50 and 0.04-0.95, respectively (Table 5). Carbon preference index (CPI) values range from 0.99 to 1.04 . Waxiness index (WI) and $n-\mathrm{C}_{17} / n-\mathrm{C}_{27}$ ratio, which compare the amount of short- to that of long-chained alkanes, vary between $0.22-0.51$ and $4.52-17.06$, respectively. The methylphenanthrene index (MPI) varies between 1.20 and 1.60 for the coal and shale samples (Table 5). Methylnaphthalene isomer ratio (MNR) and ethylnaphthalene isomer ratio (ENR) vary between 1.61 and 3.45 and 4.00 and 6.78 , respectively. The dibenzothiophene/phenanthrene ratios (DBT/Phen) range from 0.15 to 0.22 (Table 5). 
a

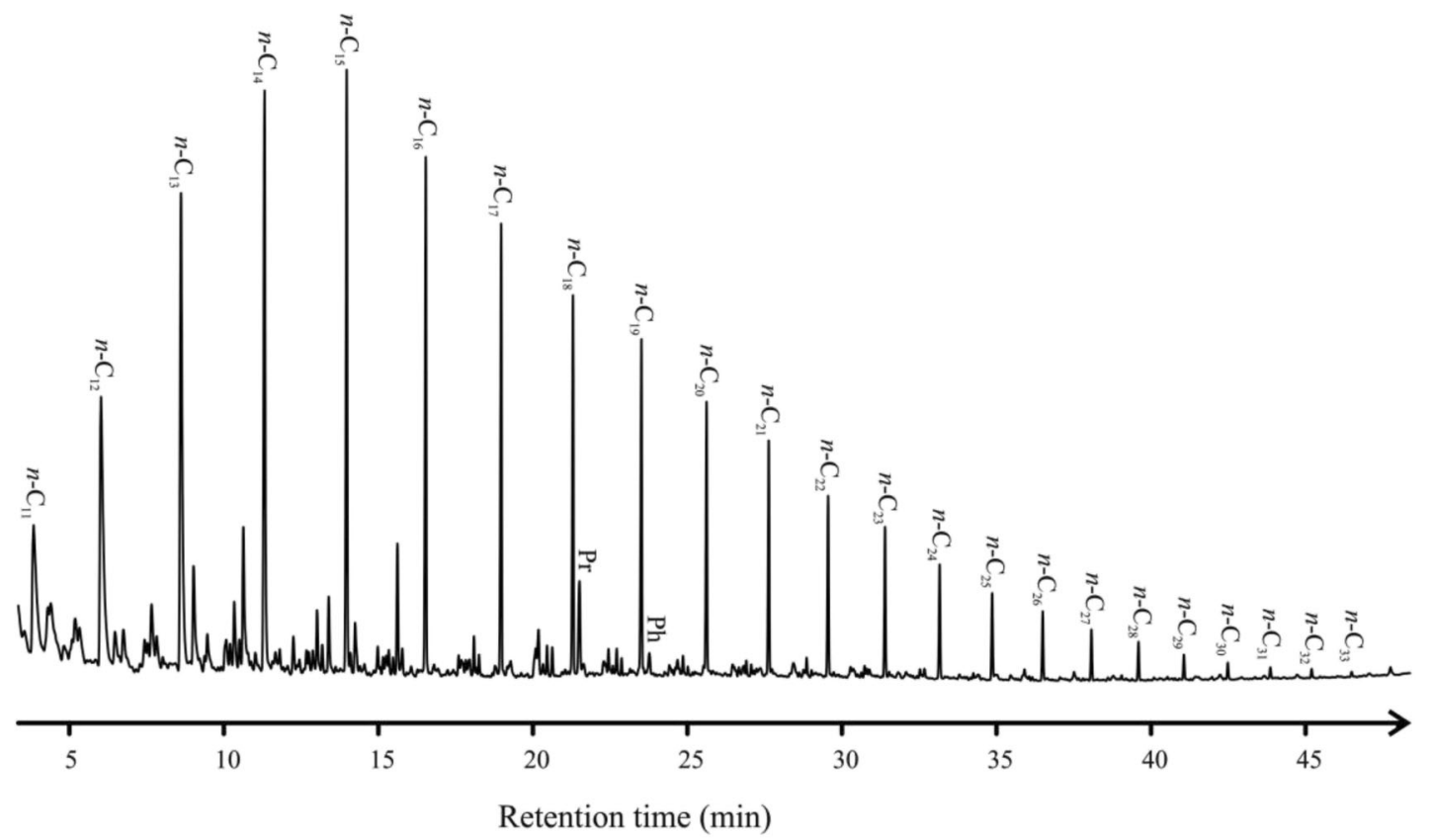

b

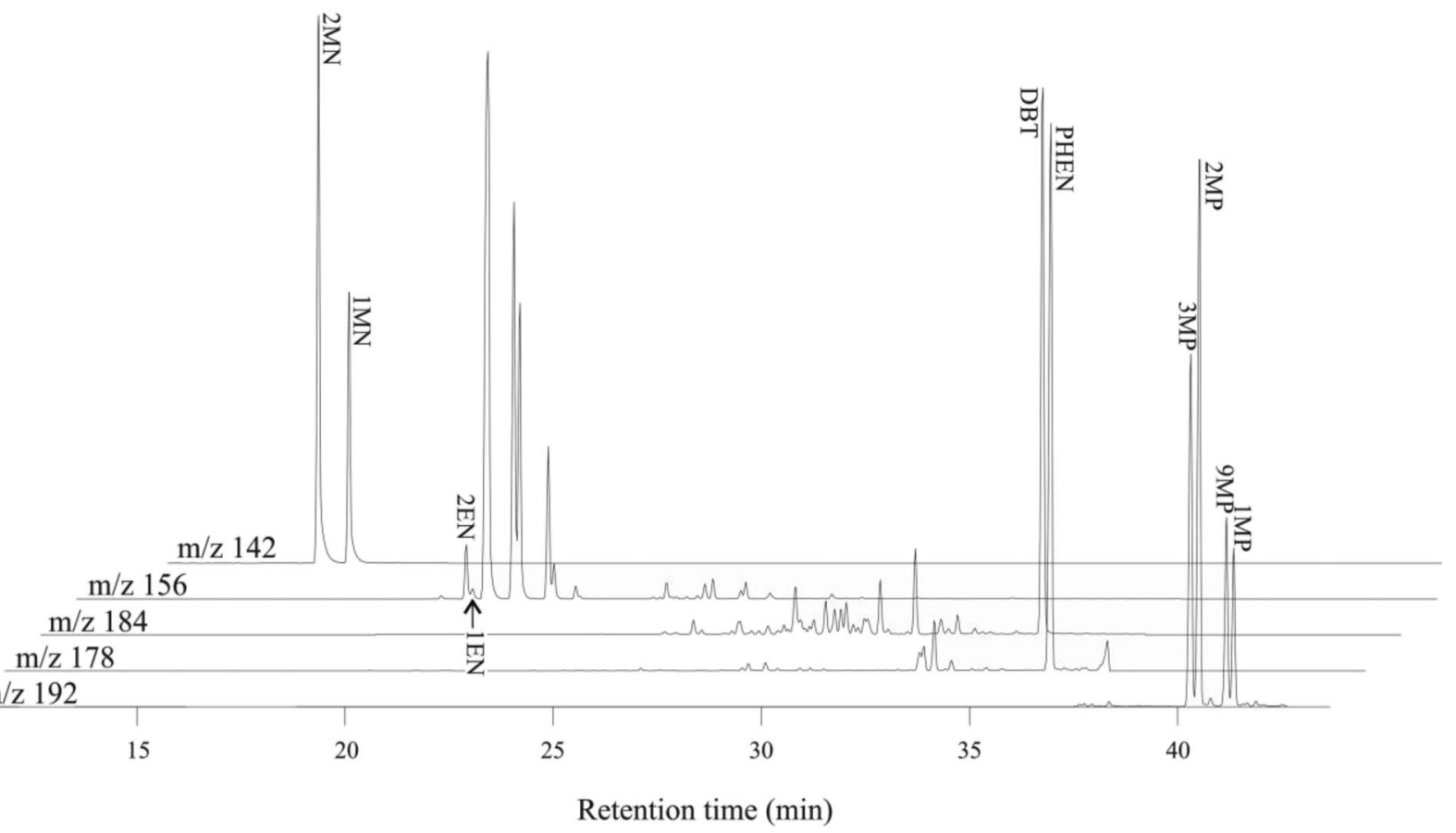

Fig. 5 a Representative GC-FID chromatogram of saturated hydrocarbons showing the distribution of $n$ - and iso-alkanes in sample $17 / 2017$ from the Parvadeh coalfield, b $M / z$ 142, 156, 184, 178 and 192 mass fragmentograms of the aromatic fraction extracted from the same sample

\section{Discussion}

\subsection{Type of organic matter and maturity}

The Parvadeh and Mazino samples show different degrees of maturity, as evidenced by vitrinite reflectance measurements. The $\mathrm{VR}_{\mathrm{r}}$ values of the Jurassic Mazino samples reveal a higher maturity compared to the Triassic shales and coals of the Parvadeh coalfield. The main petrological constituent of both, coal and shale samples analyzed is vitrinite, although inertinite content can exceed 30\%. The inertinite maceral group is more abundant in the Jurassic samples, of which, however, only a small number have been analyzed (Table 4). The overall moderate HI and low OI values (Table 3 ) confirm that the organic matter studied corresponds to kerogen type III. Jasper et al. (2009) 
Table 5 GC-FID results of the aliphatic fraction and GC-MS results of the aromatic fraction of samples from the Parvadeh coalfield

\begin{tabular}{lllllllllllll}
\hline Sample & Seam & $\mathrm{Pr} / \mathrm{Ph}$ & $\mathrm{Pr} / n-\mathrm{C}_{17}$ & $\mathrm{Ph} / n-\mathrm{C}_{18}$ & $\mathrm{CPI}$ & $\mathrm{WI}$ & $\mathrm{C}_{17} / \mathrm{C}_{27}$ & $\mathrm{MPI}-1$ & $\mathrm{R}_{\mathrm{c}}$ & $\mathrm{MNR}$ & $\mathrm{ENR}$ & $\mathrm{DBT} / \mathrm{Phen}$ \\
\hline $17 / 2013$ & $\mathrm{~B} 2$ & 4.52 & 0.38 & 0.09 & 1.01 & 0.38 & 7.46 & 1.25 & 1.15 & 2.02 & 4.37 & 0.16 \\
$17 / 2014$ & $\mathrm{~B} 2$ & 3.69 & 0.69 & 0.10 & 0.99 & 0.34 & 9.99 & 1.42 & 1.25 & 1.61 & 4.57 & 0.19 \\
$17 / 2015$ & $\mathrm{C} 1$ & 3.81 & 0.37 & 0.10 & 1.00 & 0.44 & 6.37 & 1.20 & 1.12 & 2.19 & 4.56 & 0.17 \\
$17 / 2016$ & $\mathrm{C} 1$ & 3.74 & 0.42 & 0.12 & 1.01 & 0.36 & 8.11 & 1.30 & 1.18 & 2.00 & 4.27 & 0.19 \\
$17 / 2017$ & $\mathrm{~B} 1$ & 2.51 & 0.23 & 0.11 & 1.05 & 0.37 & 7.03 & 1.42 & 1.25 & 2.03 & 4.00 & 0.22 \\
$17 / 2018$ & $\mathrm{~B} 2$ & 2.90 & 0.16 & 0.07 & 1.03 & 0.22 & 17.06 & 1.29 & 1.17 & 3.45 & 5.82 & 0.18 \\
$17 / 2019$ & $\mathrm{C} 1$ & 3.50 & 0.11 & 0.04 & 1.01 & 0.24 & 15.84 & 1.27 & 1.16 & 3.06 & 5.86 & 0.15 \\
$17 / 2020$ & $\mathrm{C} 1$ & 5.46 & 0.35 & 0.07 & 1.00 & 0.41 & 7.86 & 1.40 & 1.24 & 1.71 & 6.78 & 0.18 \\
$17 / 2021$ & $\mathrm{D}$ & 5.25 & 0.26 & 0.06 & 1.04 & 0.24 & 16.97 & 1.43 & 1.26 & 1.63 & 5.17 & 0.19 \\
$17 / 2022$ & $\mathrm{C} 1$ & 3.90 & 0.50 & 0.14 & 1.00 & 0.51 & 4.52 & 1.60 & 1.36 & 2.29 & 4.52 & 0.18 \\
$17 / 2023$ & $\mathrm{C} 1$ & 4.71 & 0.62 & 0.14 & 1.00 & 0.40 & 8.24 & n.d. & n.d. & n.d. & n.d. & n.d. \\
\hline
\end{tabular}

$\mathrm{CPI}=2\left(n-\mathrm{C}_{23}+-n \mathrm{C}_{25}+n-\mathrm{C}_{27}+n-\mathrm{C}_{29}\right) /\left(n-\mathrm{C}_{22}+2\left(n-\mathrm{C}_{24}+n-\mathrm{C}_{26}+n-\mathrm{C}_{28}\right)+n-\mathrm{C}_{30}\right)($ Bray and Evans 1961; Peters et al. 2005)

$\mathrm{WI}=\Sigma\left(n \mathrm{C}_{21}-n \mathrm{C}_{31}\right) / \Sigma\left(n \mathrm{C}_{15}-n \mathrm{C}_{20}\right)$ (Peters et al. 2005)

MPI-1 = 1.89(2-MP + 3-MP)/(P + 1.26(1-MP + 9-MP)) (Cassani et al. 1988)

$\mathrm{MNR}=2-\mathrm{MN} / 1-\mathrm{MN}$ (Radke et al. 1982b)

$\mathrm{ENR}=$ 2-EN/1-EN (Radke et al. 1982b)
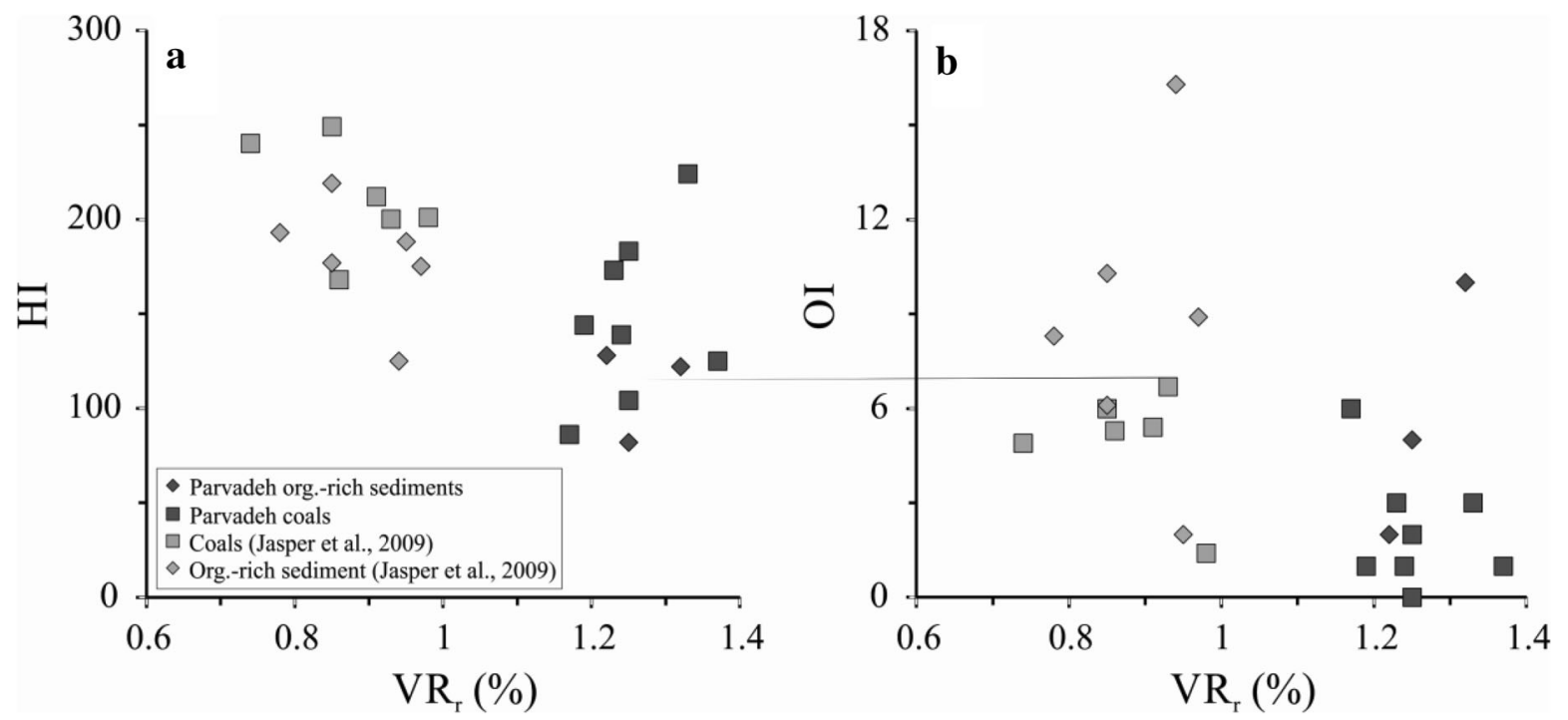

Fig. 6 Binary diagrams of HI (a) and OI (b) versus vitrinite reflectance of organic-rich sediments and coal samples of Parvadeh coalfields as compared to Carboniferous coal samples from Germany

reported lower $\mathrm{HI}$ and, at the same time, higher OI values of organic-rich sediments as compared to the associated coals for a set of Carboniferous samples from Germany. The same observation can be made for the analyzed samples (Fig. 6a, b): the highest HI values occur in coal samples and the average OI values are higher in the organic matter-rich sediments and lower in the coals. This might be explained by stronger degradation of the kerogen in the presence of mineral matter and/or mineral matrix effects (Espitalié et al. 1984; Jasper et al. 2009).
Coal-rich sedimentary sequences are ideally suited to study the relationship between optical and geochemical maturity parameters. This is due to the fact that the optical parameters, especially vitrinite reflectance, can be determined with great certainty on coals, whereas there are many pitfalls in other sedimentary sequences, in particular marine sediments, e.g. to the scarcity of vitrinite or the presence of resedimented vitrinite particles (HartkopfFröder et al. 2015). Accordingly, some molecular geochemical parameters, suitable for rather high levels of maturity as reached by the Triassic coals (about $1.2 \% \mathrm{VR}_{\mathrm{r}}$ ) 
are discussed below. A well-established maturity-indicating ratio based on the distribution of $n$-alkanes is the CPI, introduced by Bray and Evans (1961). This index is usually high $(>1)$ for low mature organic-rich sediments, and its value converges towards 1 for samples of high thermal maturity. CPI ratios of the Parvadeh samples show no predominance of odd- or even-numbered $n$-alkanes (Table 5) indicating high thermal maturity. There is no difference with respect to this parameter between coals and organic matter-rich shales. As indicated by Fig. 5, all samples from the Parvadeh coalfield show a dominance of short-chain $\left(n-\mathrm{C}_{11}-n-\mathrm{C}_{23}\right)$ over long chain $n$-alkanes $(>n$ $\mathrm{C}_{23}$ ), which can be explained by the high thermal maturity rather than the influence of aquatic organic matter input.

MPI-1, MNR, and ENR are maturity indices calculated based on GC-MS results measured on the aromatic fraction extracted from coal and shale samples. The methylphenanthrene index (MPI-1) is a well-established indicator for maturity, in particular for type III kerogen. MPI-1 increases with increasing maturity until $\mathrm{VR}_{\mathrm{r}}$ values of about $1.35 \%$ are reached and then decreases with further thermal maturity (Radke et al. 1982a; Radke and Welte 1983). While values of the organic-rich sediments from the
Parvadeh deposit correlate well with those of sediments from the Canada Basin (Fig. 7a), the MPI-1 ratio of the coals more or less constantly increase with $\mathrm{VR}_{\mathrm{r}}$ (Fig. 7b). The turning point from positive to negative correlations with vitrinite reflectance seems to be at higher thermal maturities for coals as compared to dispersed organic matter of the same kerogen type. Willsch and Radke (1995) reported a stagnation of MPI-1 values of coals around $1.65 \% \mathrm{VR}_{\mathrm{r}}$, and data published by Radke et al. (1982b) showed that MPI-1 values constantly increased for a sample-set of coals with maturities ranging from $0.63 \%$ to $1.70 \% \mathrm{VR}_{\mathrm{r}}$. From MPI-1 values, vitrinite reflectance $\left(\mathrm{R}_{\mathrm{c}}\right)$ can be calculated (Table 5). The calculated reflectance $\left(R_{c}\right)$ shows values similar to the measured reflectance for the coal samples but is slightly lower for the organic matterrich shale samples (Table 5). A positive correlation with $\mathrm{VR}_{\mathrm{r}}$ is also observed for the MNR values (Fig. 7c); while the values are in the range expected for coals of medium volatile bituminous rank (Radke et al. 1994).
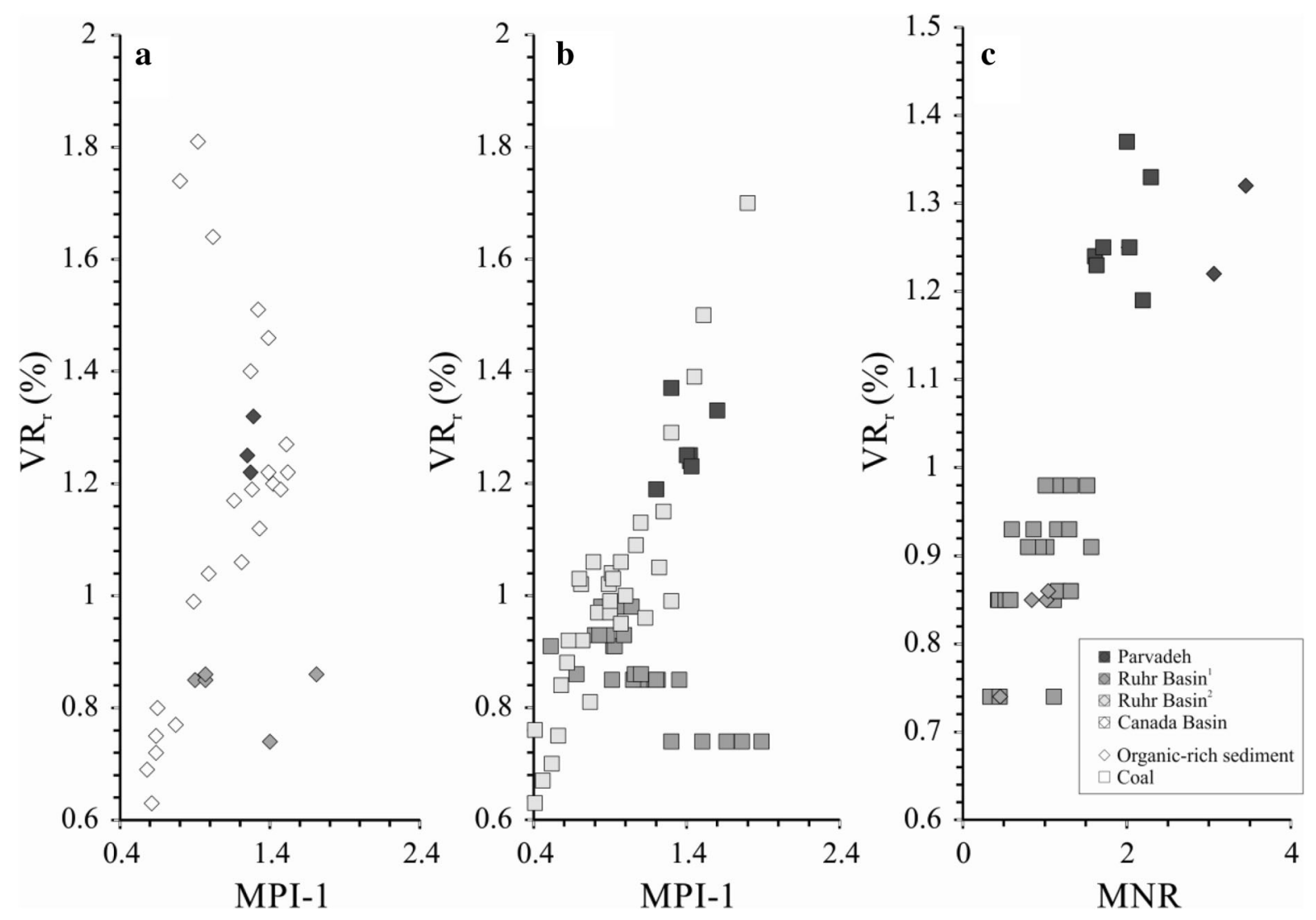

Fig. 7 Variation in MPI-1 values of the Parvadeh samples with maturity of: a organic-rich sediments in comparison to values reported for other basins (data from samples from the Ruhr ${ }^{1}$ and Canada Basin from Böcker et al. 2013; Radke et al. 1982a), b coals (data from the Ruhr Basin ${ }^{2}$ from Radke et al. 1982b), c MNR values of the Parvadeh samples showing high maturities 


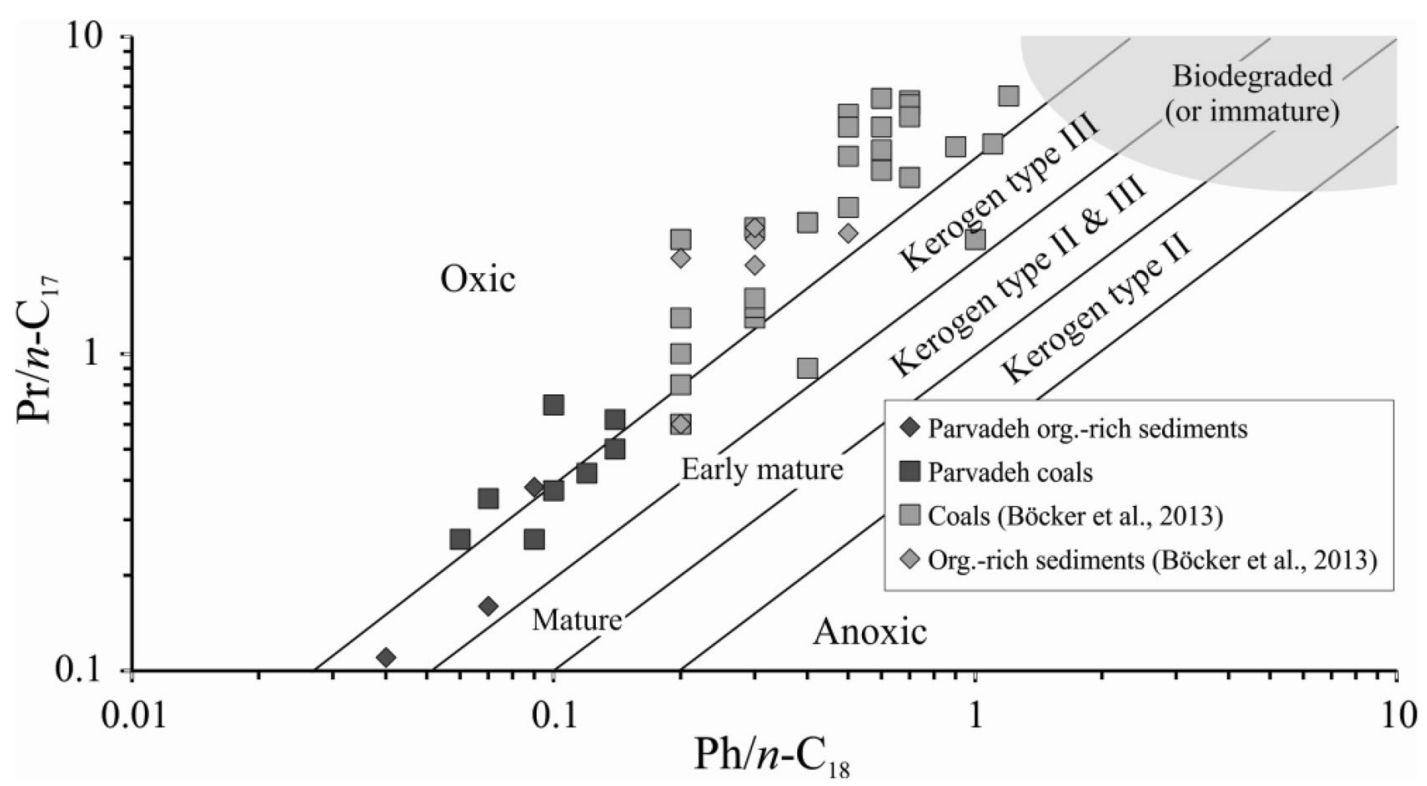

Fig. 8 Pristane/ $n$-C17 versus Phytane $n$-C18 plot after Shanmugam (1985) showing the Parvadeh samples in comparison to less mature samples from the Ruhr Basin (Germany)

\subsection{Depositional environment}

The high vitrinite contents of the Jurassic and Triassic samples are typical for humic coals and associated organic matter-rich sediments. High $\mathrm{Pr} / \mathrm{Ph}$ ratios of the Parvadeh samples give further evidence for a predominantly terrigenous plant input. The $\mathrm{Pr} / \mathrm{Ph}$ ratio has also been used to determine the redox conditions during sedimentation (Didyk et al. 1978), although other factors such as biogenic precursor material and thermal alteration have to be considered as well (Ten Haven et al. 1987). The ratios of $\operatorname{Pr} / n$ $\mathrm{C}_{17}$ and $\mathrm{Ph} / n-\mathrm{C}_{18}$ point towards a deposition under oxic conditions, typical for coals and organic matter-rich sediments from coal-bearing strata rich in kerogen type III. Figure 8 shows a positive correlation of $\mathrm{Pr} / n-\mathrm{C}_{17}$ vs. $\mathrm{Ph} / n$ $\mathrm{C}_{18}$ ratios of the Parvadeh samples and samples of lower mature bituminous coals and shales from the Ruhr Basin (Germany). Both ratios are exceptionally low in two of the Parvadeh shales if compared to the coals, probably indicating stronger thermal degradation of pristane and phytane in the shales as compared to the coals rather than more reducing depositional environments. Information on the depositional setting of organic sediments can also be obtained by cross-plotting the DBT/Phen ratio versus the $\mathrm{Pr} / \mathrm{Ph}$ ratio (Hughes et al. 1995). Because of high $\mathrm{Pr} / \mathrm{Ph}$ and very low DBT/Phen values, the coal and shale samples from the Parvadeh coal field fall into the fluvial/deltaic zone (Fig. 9) thus supporting the indications drawn from the parameters discussed above. Aside from maceral composition and molecular geochemical parameters, information on depositional environment can also be

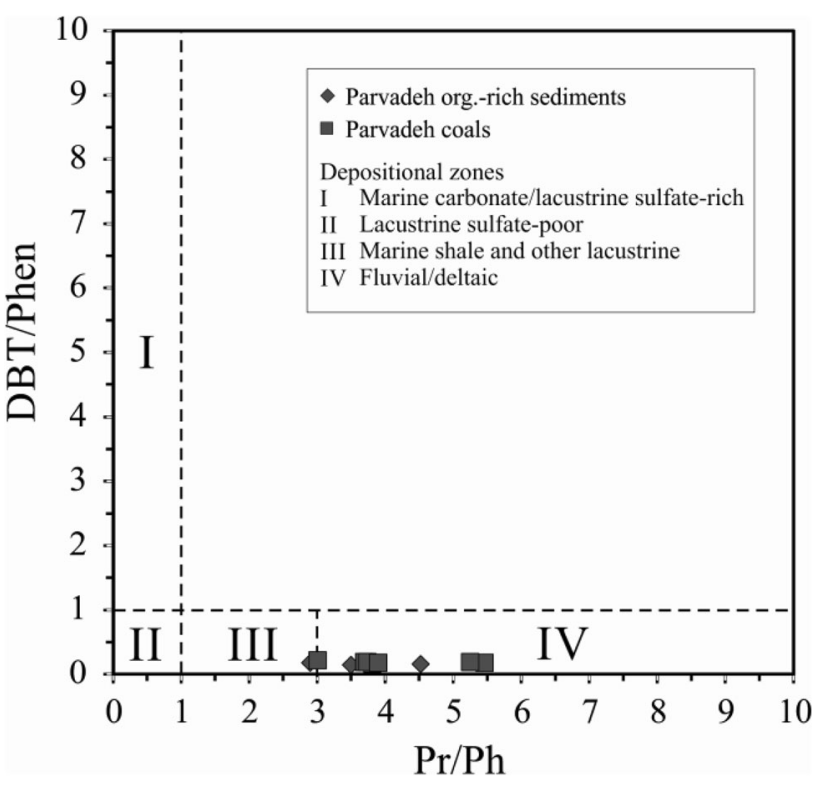

Fig. 9 Organic-rich sediments and coal samples of the Parvadeh coalfield plotted in the DBT/Phen against $\mathrm{Pr} / \mathrm{Ph}$ diagram of Hughes et al. (1995) showing the depositional setting

deduced from the elemental composition, in particular sulfur-organic carbon relationships (Berner 1984). Sulfurcontaining amino acids and other organic compounds of the peat-forming plants as well as some pyrite/marcasite are the most abundant types of sulfur present in freshwaterinfluenced coals (Casagrande et al. 1980; Chou 2012). Most of the sulfur in coals is of syngenetic origin, formed during early diagenesis at the peat stage (Casagrande et al. 1980). The total sulfur (TS) content can be used as 


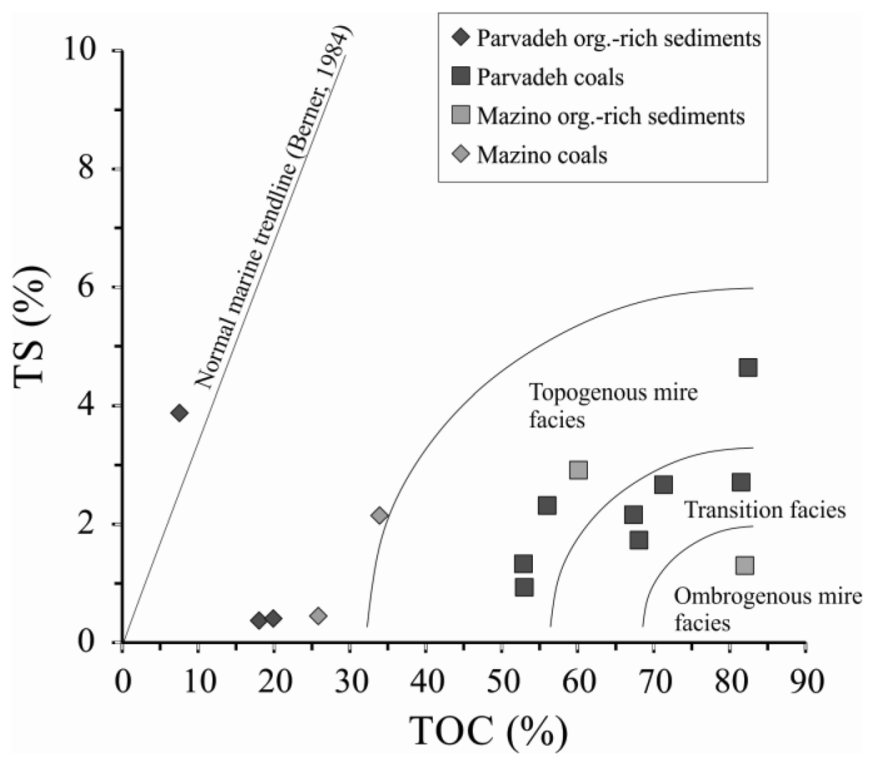

Fig. 10 Binary diagram of TS versus TOC for organic-rich sediment and coal samples of the Parvadeh and Mazino coalfields. Depositional facies after Jasper et al. (2010)

indicative for marine influence on the coal forming peat, as seawater is enriched in sulfate and interactions of seawater and organic matter leads to the formation of abundant pyrite due to the activities of sulfate reducing bacteria (Casagrande et al. 1977; Given and Miller 1985). The amount of sulfur in coals not affected by marine waters is around $0.5 \%$, and increases to $0.5 \%-1.5 \%$ and $>1.5 \%$ in coals which became subject to slight or strong marine influence, respectively (Sykes et al. 2014; Stock et al. 2016). The interpretive TOC/TS plot developed by Jasper et al. (2010) reveals that the Triassic coals plot in the field of topogenic to transitional mires, but not in the field of ombrogenous mires. Some coals might have been influenced by marine flooding as indicated by quite high TS/ TOC ratios (Fig. 10). In addition, one of the organic matter-rich Parvadeh shales plots along the normal marine line (Berner 1984), also suggesting periodic marine flooding.

\subsection{Temperature history}

Maturity data clearly prove an advanced maturation of coal-bearing rocks in both the Parvadeh and Mazino area. Such high maturation can be due to either a deep burial of the rocks (at low-moderate basal heat flows) or a moderate burial at high heat flows or a combination of both (Senglaub et al. 2006). Considering the present-day geology and heat flow history of the region (Table 2) an erosion thickness of up to $4000 \mathrm{~m}$ is necessary to reach the measured maturity data and calibration in Parvadeh area. This thickness of now eroded sedimentary rocks is slightly higher than the reported total thickness of the upper Jurassic-Eocene succession of type sections in Central Iran
(Aghanabati 1998; Shahrabi 1999). Erosion is assumed to have occurred during the Alpine Orogeny (Fig. 11a). The coal-bearing Triassic succession was accordingly at maximum burial depth $(4500 \mathrm{~m})$ during the Late Eocene/Early Oligocene (Fig. 11a). Following the Alpine Orogeny, uplift and erosion in the region the burial depth decreased to around $500 \mathrm{~m}$ at present-day. Due to the absence of major peaks in Jurassic to Eocene heat flow, the upper Triassic succession also experienced the highest temperature $\left(150{ }^{\circ} \mathrm{C}\right)$ during the Late Eocene/Early Oligocene with the onset of uplift and erosion. Temperature decreased to about $35^{\circ} \mathrm{C}$ at present-day. The maximum thermal maturity of $1.2 \% \mathrm{VR}_{\mathrm{r}}$ was also reached during the Late Eocene/Early Oligocene remaining constant up to present-day.

Vitrinite reflectance values are even higher (Table 3) in the Mazino area, and thus maximum paleo-temperatures must have also exceeded those in the Parvadeh area $\left(150{ }^{\circ} \mathrm{C}\right)$. In this region, the thermal maturity of the Upper Jurassic succession reached more than $2 \% \mathrm{VR}_{\mathrm{r}}$. Such maturity variations can be explained by either greater burial depth, higher heat flows, thrust faulting and hydrothermal fluids or a combination of these factors (Ruppert et al. 2010; Hower et al. 2019). Assuming the same burial depth (about $4500 \mathrm{~m}$ ), such maturities will be reached by applying basal heat flow values of 80 instead of $50 \mathrm{~mW} \mathrm{~m}^{-2}$ during maximum burial in the Late Eocene (Fig. 11b); or by assuming a much thicker eroded sequence of about $6000 \mathrm{~m}$ in this area (at the same heat flows in the Parvadeh area). Although there is no justified evidence, we cannot rule out the possibility of short-term thermal events caused by volcanic intrusions and hydrothermal fluids. Whereas the data for the Parvadeh area seem to fit well 

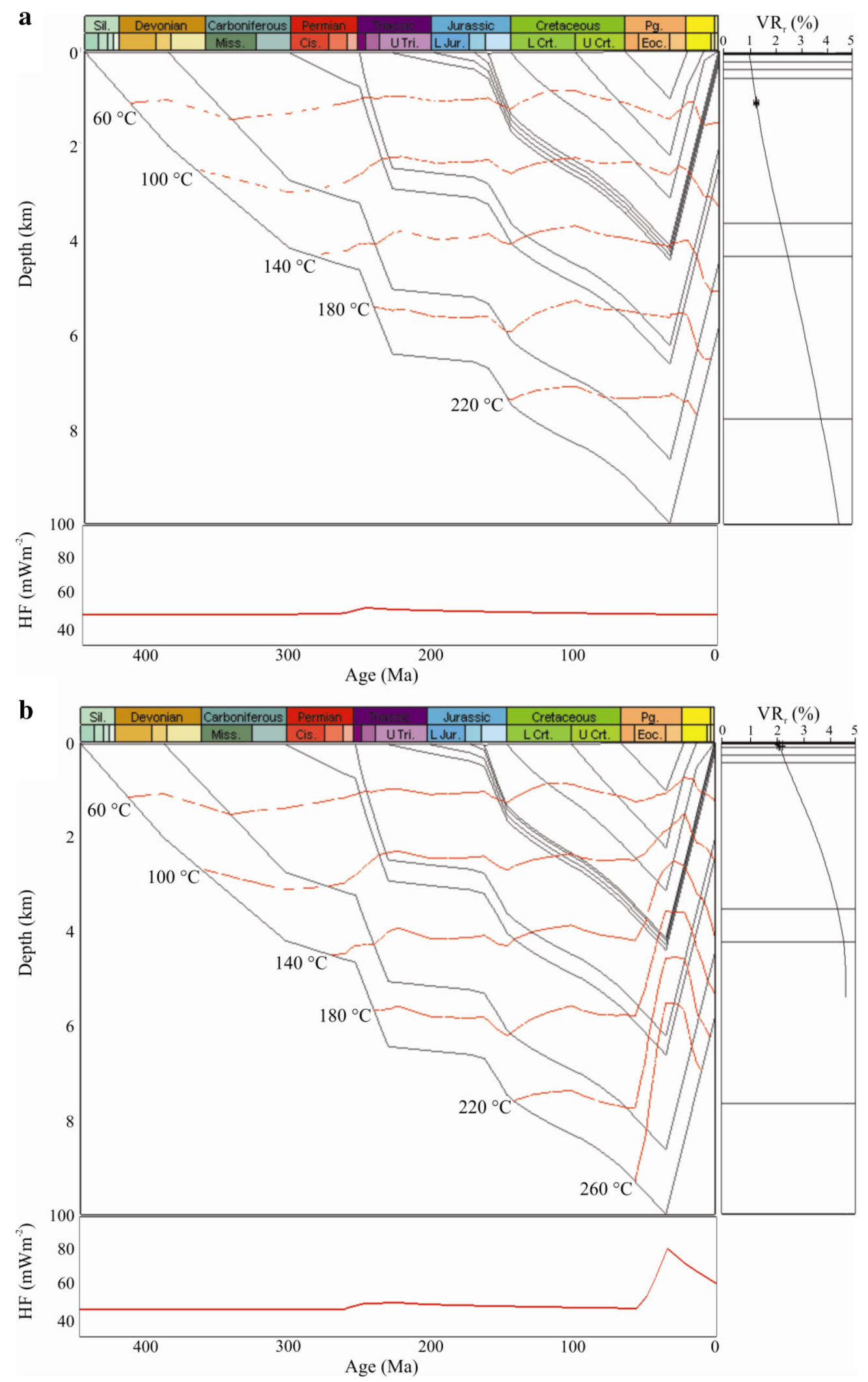

Fig. 11 Burial and thermal history at the locations of Parvadeh (a) and Mazino (b) including basal heat flow history and model calibration. 
with geological data and the paleo-geothermal regime, more information is needed to understand the data for the Mazino region (e.g. apatite fission track data).

\section{Conclusions}

Triassic coals and organic matter-rich sedimentary rocks of the Parvadeh coalfield are characterized by abundant vitrinite and less inertinite and a vitrinite reflectance of about $1.2 \%-1.3 \% \mathrm{VR}_{\mathrm{r}}$. Ash contents of these medium volatile bituminous coals are usually high, whereas sulfur contents are variable, but mostly high. Jurassic coals and organic matter-rich sedimentary rocks of the Mazino coal field are more mature, with vitrinite reflectance values of about $2.0 \%$ to $2.2 \% \mathrm{VR}_{\mathrm{r}}$. Some of these rocks are rich in inertinite, especially the coals. Similar to the Parvadeh samples, ash contents are mostly high and sulfur contents variable, but often high. Based on the TOC-sulfur relationship, it can be deduced that most coals are derived from topogeneous or transitional mires, but not from ombrogeneous mires. Organic geochemical maturity parameters were tested on these samples and compared to vitrinite reflectance. Differences were observed for coals and other rocks with respect to the evolution of the methyl phenanthrene index at high levels of maturity, i.e. MPI-1 further increases for coals whereas in shales, it reaches the turnaround point at about $1.3 \% \mathrm{VR}_{\mathrm{r}}$ and then decreases. In case of the Triassic coals, MNR values are higher for shales than for coals of the same maturity, whereas $\mathrm{Pr} / n-\mathrm{C}_{17}$ and $\mathrm{Ph} / n$ $\mathrm{C}_{18}$ ratios are lower. Modeling at the location of Parvadeh coalfield indicates the necessity of about $4000 \mathrm{~m}$ erosion which probably occurred during the Alpine Orogeny in order to reach the present-day thermal maturity of the Triassic successions applying basal heat flow of approx. $50 \mathrm{~mW} \mathrm{~m}^{-2}$. At the location of Mazino coalfield the present-day thermal maturity which is higher than the Parvadeh area will reach either with higher erosion amounts of about $6000 \mathrm{~m}$ or heat flow of up to $80 \mathrm{~mW} \mathrm{~m}^{-2}$. Magmatic intrusions can have caused the high heat flow in the area of the Mazino coals.

\begin{abstract}
Acknowledgements The authors would like to appreciate the Energy and Mineral Resources Group (EMR), RWTH Aachen University, Germany and Shiraz University Research Council, Iran for their financial support of this work. We further acknowledge Dr. S. Peng, the Editor-in-Chief of International Journal of Coal Science \& Technology, and Professor J. Hower for constructive comments on an earlier draft of the manuscript.
\end{abstract}

Open Access This article is distributed under the terms of the Creative Commons Attribution 4.0 International License (http://crea tivecommons.org/licenses/by/4.0/), which permits unrestricted use, distribution, and reproduction in any medium, provided you give appropriate credit to the original author(s) and the source, provide a link to the Creative Commons license, and indicate if changes were made.

\section{References}

Aghanabati SA (1998) Jurassic stratigraphy of Iran. Geological Survey of Iran, Tehran (in Persian)

Ahangaran DK, Afzal P, Yasrebi AB, Wetherelt A, Foster PJ, Alvan Darestani R (2011) An evaluation of the quality of metallurgical coking coal seams within the north block of Eastern Parvadeh coal deposit, Tabas, Central Iran. J Min Metall 47(1):9-24

Alavi M (1996) Tectonostratigraphic synthesis and structural style of the Alborz Mountains System in northern Iran. J Geodyn 21(1):1-33

Alizadeh B, Alipour M, Hosseini SH, Jahangard AA (2011) Paleoenvironmental reconstruction using biological markers for the Upper Triassic-Middle Jurassic sedimentary succession in Tabas Basin, central Iran. Org Geochem 42:431-437

Alizadeh B, Alipour M, Habibnia B, Gandomi-Sani AR, Khani B, Shirvani S, Jahangard AA (2015) Organic geochemistry and paleoenvironments of deposition of the Middle Jurassic sediments from the Tabas Basin, Central Iran. Iran J Oil Gas Sci Technol 4(1):17-34

Ardebili L, Babazadeh V, Mammadov M, Navi P (2012) Geochemical characteristics of Galandrud coal in central Alborz, Iran. Int J Min Sci Technol 22(1):101-106

Behar F, Beaumont V, Penteado HDB (2001) Rock-Eval 6 technology: performances and developments. Oil Gas Sci Technol 56(2):111-134

Berner RA (1984) Sedimentary pyrite formation: an update. Geochim Cosmochim Acta 48(4):605-615

Böcker J, Littke R, Hartkopf-Fröder C, Jasper K, Schwarzbauer J (2013) Organic geochemistry of Duckmantian (Pennsylvanian) coals from the Ruhr Basin, western Germany. Int J Coal Geol 107:112-126

Bordenave ML, Hegre JA (2005) The Influence of Tectonics on the Entrapment of Oil in the Dezful Embayment, Zagros Foldbelt, Iran. J Pet Geol 28:339-368

Bray EE, Evans ED (1961) Distribution of n-paraffins as a clue to recognition of source beds. Geochim Cosmochim Acta 22:2-15

Casagrande D, Siefert L, Berschinski C, Sutton N (1977) Sulfur in peat-forming systems of the Okefenokee Swamp and Florida Everglades: origins of sulfur in coal. Geochim Cosmochim Acta 41(1):161-167

Casagrande DJ, Grondli K, Sutton N (1980) The distribution of sulfur and organic matter in various fractions of peat: origins of sulfur in coal. Geochim Cosmochim Acta 44(1):25-32

Cassani F, Gallango O, Talukdar S, Vallejos C, Ehrmann U (1988) Methylphenanthrene maturity index of marine source rock extracts and crude oils from the Maracaibo Basin. Org Geochem Pet Explor 13:73-80

Chou LC (2012) Sulfur in coals: a review of geochemistry and origins. Int J Coal Geol 100:1-13

Darvishzadeh A (1991) Geology of Iran. Amir Kabir Publication, Tehran (in Persian)

Didyk BM, Simoneit BRT, Brassell SC, Eglinton G (1978) Organic geochemical indicators of palaeoenvironmental conditions of sedimentation. Nature 272:216-222

Durand B, Monin JC (1980) Elemental analysis of kerogens (C, H, O, $\mathrm{N}, \mathrm{S}, \mathrm{Fe}$ ). In: Durand B (ed) Kerogen. Technip, Paris, pp 113-142

Espitalié J, Makadi KS, Trichet J (1984) Role of the mineral matrix during kerogen pyrolysis. Org Geochem 6:365-382 
Fürsich FT, Wilmsen M, Seyed-Emami K, Majidifard MR (2009) The Mid- Cimmerian tectonic event (Bajocian) in the Alborz Mountains, northern Iran: evidence of the break-up unconformity of the South Caspian Basin. In: Brunet MF, Wilmsen M, Granath JW (eds) South Caspian to central Iran Basins. Geological Society of London, Special Publications, pp 189-203

Ghassabiyan N, Saidi A, Aghanabati A, Qorashi M, Ghasemi MR (2010) Geohistory analysis of the Tabas Block (AbdoughiParvadeh Basins) as SEEN from the Late Triassic through Early Cretaceous subsidence curves. J Sci Islam Repub Iran 21(1):49-63

Ghavidel-Syooki M, Yousefi M, Shekarifard A, Mohnhoff D (2015) Palynostratigraphy, palaeogeography and source rock evaluation of the Nayband Formation at the Parvadeh area, Central Iran, Iran. J Sci Islam Repub Iran 26(3):241-263

Given PH, Miller RN (1985) Distribution of forms of sulfur in peat from saline environments in the Florida Everglades. Int J Coal Geol 5(4):397-409

Goodarzi F, Sanei H, Stasiuk LD, Bagheri-Sadeghi H, Reyes J (2006) A preliminary study of mineralogy and geochemistry of four coal samples from northern Iran. Int J Coal Geol 65(1-2):35-50

Hantschel T, Kauerauf AI (2009) Fundamentals of basin and petroleum systems modeling. Springer, Berlin

Hartkopf-Fröder C, Königshof P, Littke R, Schwarzbauer J (2015) Optical thermal maturity parameters and organic geochemical alteration at low grade diagenesis to anchimetamorphism: a review. Int J Coal Geol 150:74-119

Hower JC, Rimmer SM, Mastalerz M, Wagner NJ (2019) Notes on the mechanisms of coal metamorphism in the Pennsylvania Anthracite Fields. Int J Coal Geol 202:161-170

Hughes WB, Holba AG, Dzou LI (1995) The ratio of dibenzothiophene to phenanthrene and pristane to phytane as indicators of depositional environment and lithology of petroleum source rocks. Geochim Cosmochim Acta 59(17):3581-3598

Jarvis GT, McKenzie DP (1980) Sedimentary basin formation with finite extension rates. Earth Planet Sci Lett 48:42-52

Jasper K, Krooss BM, Flajs G, Hartkopf-Fröder C, Littke R (2009) Characteristics of type III kerogen in coal-bearing strata from the Pennsylvanian (Upper Carboniferous) in the Ruhr Basin, Western Germany: comparison of coals, dispersed organic matter, kerogen concentrates and coal-mineral mixtures. Int $\mathrm{J}$ Coal Geol 80(1):1-19

Jasper K, Hartkopf-Fröder C, Flajs G, Littke R (2010) Evolution of Pennsylvanian (Late Carboniferous) peat swamps of the Ruhr Basin, Germany: comparison of palynological, coal petrographical and organic geochemical data. Int $J$ Coal Geol 83(4):346-365

Konon A, Nadimi A, Koprianiuk M, Wysocka A, Szaniawski R, Wyglądała M, Słaby E, Beygi S, Barski M (2016) Formation of intracontinental basins in the opposite corners of the Tabas block as coeval structures controlled by transpressional faulting, Iran. GSA Bull 128(11-12):1593-1617

Littke R, Urai JL, Uffmann AK, Risvanis F (2012) Reflectance of dispersed vitrinite in Palaeozoic rocks with and without cleavage: implications for burial and thermal history modeling in the Devonian of Rursee area, northern Rhenish Massif, Germany. Int J Coal Geol 89:41-50

Mattei M, Cifelli F, Muttoni G, Rashid H (2015) Post-Cimmerian (Jurassic-Cenozoic) paleogeography and vertical axis tectonic rotations of Central Iran and the Alborz Mountains. J Asian Earth Sci 102:92-101

Molinaro M, Zeyen H, Laurencin X (2005) Lithospheric structure beneath the south-eastern Zagros Mountains, Iran: recent slab break-off? Terra Nova 17(1):1-6
Moore F, Esmaeili A (2012) Mineralogy and geochemistry of the coals from the Karmozd and Kiasar coal mines, Mazandaran province, Iran. Int J Coal Geol 96-97:9-21

Moosavirad SM, Rasouli J, Janardhana MR, Moghadam MR, Shankara M (2013) Petrographic, mineralogy, and geochemistry of coals of Pabedana, Kerman Province, Central Iran. Arab J Geosci 6(10):3623-3634

Motavalli-Anbaran SH, Zeyen H, Brunet MF, Ardestani VE (2011) Crustal and lithospheric structure of the Alborz Mountains, Iran, and surrounding areas from integrated geophysical modeling. Tectonics TC30:5012. https://doi.org/10.1029/2011tc002934

Nöth S, Karg H, Littke R (2001) Reconstruction of Late Paleozoic heat flows and burial histories at the Rhenohercynian-Subvariscan boundary, Germany. Int J Earth Sci 90(2):234-256

Pazand K (2015) Rare earth element geochemistry of coals from the Mazino Coal Mine, Tabas Coalfield, Iran. Arab J Geosci 8(12):10859-10869

Peters KE, Walters CC, Moldowan JM (2005) The biomarker guide volume 2: biomarkers and isotopes in petroleum exploration and earth history, 2nd edn. Cambridge University Press, Cambridge

Radke M, Welte DH (1983) The methylphenanthrene index (MPI). A maturity parameter based on aromatic hydrocarbons. Adv Org Geochem 1981:504-512

Radke M, Welte DH, Willisch H (1982a) Geochemical study on a well in the Western Canada Basin: relation of the aromatic distribution pattern to maturity of organic matter. Geochim Cosmochim Acta 46(1):1-10

Radke M, Willsch H, Leythaeuser D (1982b) Aromatic components of coal: relation of distribution pattern to rank. Geochim Cosmochim Acta 46(10):1831-1848

Radke M, Rullkötter J, Vriend SP (1994) Distribution of naphthalenes in crude oils from the Java Sea: source and maturation effects. Geochim Cosmochim Acta 58(17):3675-3689

Ragot JP (1977) Contribution à l'étude de l'évolution des substances carbonées dans les formations géologiques. Univ. P. Sabatier, Toulouse, Thesis, $150 \mathrm{pp}$

Rajabzadeh MA, Ghorbani Z, Keshavarzi B (2016) Chemistry, mineralogy and distribution of selected trace-elements in the Parvadeh coals, Tabas, Iran. Fuel 174:216-224

Ruppert LF, Hower JC, Ryder RT, Levine JR, Trippi MH, Grady WC (2010) Geologic controls on thermal maturity patterns in Pennsylvanian coal-bearing rocks in the Appalachian basin. Int J Coal Geol 81(3):169-181

Sachse VF, Littke R, Heim S, Kluth O, Schober J, Boutib L, Sindern S (2011) Petroleum source rocks of the Tarfaya Basin and adjacent areas, Morocco. Org Geochem 42(3):209-227

Senglaub Y, Littke R, Brix MR (2006) Numerical modelling of burial and temperature history as an approach for an alternative interpretation of the Bramsche anomaly, Lower Saxony Basin. Int J Earth Sci 95(2):204-224

Shahrabi M (1999) Triassic in Iran. Geological Survey of Iran, Tehran (in Persian)

Shanmugam G (1985) Significance of coniferous rain forests and related organic matter in generating commercial quantities of oil, Gippsland Basin. AAPG Bull 69(8):1241-1254

Solaymani Z, Taghipour N (2012) Petrographic characteristics and palaeoenvironmental setting of Upper Triassic Olang coal deposits in northeastern Iran. Int J Coal Geol 92:82-89

Stampfli GM, Borel GD (2002) A plate tectonic model for the Paleozoic and Mesozoic constrained by dynamic plate boundaries and restored synthetic oceanic isochrons. Earth Planet Sci Lett 196(1):17-33

Stasiuk LD, Goodarzi F, Bagheri-Sadeghi H (2006) Petrology, rank and evidence for petroleum generation, upper Triassic to Middle Jurassic coals, central Alborz Region, Northern Iran. Int J Coal Geol 67(4):249-258 
Stock AT, Littke R, Lücke A, Zieger L, Thielemann T (2016) Miocene depositional environment and climate in western Europe: the lignite deposits of the lower Rhine Basin, Germany. Int J Coal Geol 157:2-18

Stöcklin J, Eftekhar-Nezhad J, Hushmand-zadeh A (1965) Geology of the Shotori range (Tabas area, East Iran). Geological survey of Iran, Report No. 3, 69 pp

Sweeney JJ, Burnham AK (1990) Evaluation of a simple model of vitrinite reflectance based on chemical kinetics. AAPG Bull 74(10): $1559-1570$

Sykes R, Volk H, Georgec SC, Ahmed M, Higgs KE, Johansen PE, Snowdon LR (2014) Marine influence helps preserve the oil potential of coaly source rocks: eocene Mangahewa Formation, Taranaki Basin, New Zealand. Org Geochem 66:140-163

Takin M (1972) Iranian geology and continental drift in the Middle East. Nature 235:147-150

Taylor GH, Teichmüller M, Davis A, Diessel CFK, Littke R, Robert P (1998) Organic petrology. Gebrüder Bornträger, Stuttgart

Ten Haven HL, De Leeuw JW, Rullkötter J, Damsté JS (1987) Restricted utility of the pristane/phytane ratio as a palaeoenvironmental indicator. Nature 330(6149):641-643
Tunini L, Jiménez-Munt I, Fernandez M, Vergés J, Villaseñor A (2015) Lithospheric mantle heterogeneities beneath the Zagros Mountains and the Iranian Plateau: a petrological-geophysical study. Geophys J Int 200(1):596-614

Willsch H, Radke M (1995) Distribution of polycyclic aromatic compounds in coals of high rank. Polycyclic Aromat Compd 7:231-251

Wilmsen M, Fürsich FT, Seyed-Emami K, Majidifard MR (2009) An overview of the stratigraphy and facies development of the Jurassic System on the Tabas Block, east-central Iran. Geol Soc Lond Spec Publ 312(1):323-343

Wygrala BP (1989) Integrated study of an oil field in the southern Po basin, Northern Italy. Jülich Reports, Jülich, 217 pp

Yazdi M, Shiravani AE (2004) Geochemical properties of coals in the Lushan coalfield of Iran. Int J Coal Geol 60(1):73-79

Zieger L, Littke R, Schwarzbauer J (2018) Chemical and structural changes in vitrinites and megaspores from carboniferous coals during maturation. Int J Coal Geol 185:91-102 